\title{
VOTE BUYING AND DEMOCRATIC ELECTIONS IN NIGERIA
}

\author{
https://doi.org/10.47743/jopafl-2021-20-05
}

\author{
Peter Nick ESSIEN \\ Department of Political Science And International Relations, College of Leadership \\ Development Studies, Covenant University, \\ Ota, Ogun State, Nigeria \\ cremmypit@gmail.com
}

Ejiroghene A. OGHUVBU

Department of History and International Studies, Faculty of Arts, Delta State University, Abraka, Nigeria

augustine4best@yahoo.com

\begin{abstract}
The study examines vote buying and democratic elections in Nigeria: a study of the 2018 Ekiti state gubernatorial election. Vote buying In Nigerian election is not a new phenomenon however; it has gotten a lot of spotlight as a result of its inherent ability of causing devastating effect on the body of politics and the democratic process of new democracies such as Nigeria. This is because vote buying has become an integral part of elections in Nigeria and has escalated to the point that some candidates add buying of votes as part of the political strategy, as they believe that manifestoes and integrity of candidates alone is not enough to win elections. This research therefore, aims to identify the manifestations, examine the impact, ascertain the catalyst and suggest possible mechanism to minimize vote buying in future Ekiti state elections. The study adopts the quantitative method been supported by the qualitative method of data collection and uses clientelism as the theoretical framework. The study discovered that vote buying largely affected the outcome of the 2018 Ekiti state gubernatorial election and identified some factors such as poverty, lack of voter's education and poor execution of sanctions as catalyst of vote buying. It also suggests some recommendations in the bid to curb the behavior of vote buying in future Nigerian elections. The study concluded that without tackling the catalyst of vote buying in Nigeria election, the behavior of vote buying will keep on thriving.
\end{abstract}

Keywords: Elections, Electoral Process, Vote Buying, Nigeria.

\section{Introduction}

The research examines the impact of vote buying on democratic elections in Nigeria, with specific focus on the 2018 governorship election in Ektit State. Nigeria's style of democracy can be linked to that of America which advocates that the absolute and supreme power remains with the people (Noah, 2006). This style of democracy in which Nigeria adopts is largely hinged on the premise that the will of the majority is done and the voice of the minority is heard. For democracy to thrive as a political system the basic features of democracy must be implemented which include periodic elections; the provision of fundamental human rights; multiply party system with candidates to choice from, amongst others (Noah, 2004). Periodic election, a feature of democracy can be said to be an indispensable characteristic of any democratic transition and the hallmark of representative democracy (Inokoba and Kumokor, 2011). This is because, it is during elections that the voices of the people are well heard and it is also recorded as an event 
with the highest rate of political participation by the people. Today elections are seen as the most acceptable medium by which citizens choose their leaders in an orderly, serene and peaceful exercise (Momoh, 2005). Elections could be regarded as a coin with two sides; On one side, elections give citizen's an avenue to indicate their choice amongst candidates, manifestoes, policies, ideas and programmes presented to them by individuals vying for leadership positions while on the other side, it is also an instruments for removing unpopular and ineffective leaders as well as forcing elected officials to hearken to the plight of the people (David, Manu, and Musa, 2014). This is because the electorates hold the power to renew or cancel the tenure of every elected official. These functions of election are made possible because of the provision of the electoral process; which spells out the method to be used in selecting individuals for political offices (Nnamani, 2014).

The electoral process can be said to be the sum total of the entire operation in relations to carrying out an election from as little as performing of voter education to as great as dissolving of the National Assembly (Elekwa, 2008). It is also said to be the pre and post-election duties including guidelines put in place by the electoral officials in order for the election to run smoothly as well as for the electorates to choose representative towards catering for their interest because without such activities the election is more or less void. Activities of the electoral process include registering political parties, registering and reviewing of voters' records, scheduling times for electoral campaigns, electoral disputes resolution, swearing elected representatives to mention a few (Nnamani, 2014). One of the activities as part of the electoral process is campaigning where candidates race to captivate the heart of the electorate with the hope of becoming the electorate's choice. A democratic campaign is supposed to be peaceful and serene interaction. On one hand the candidates are involved in various discourse of persuasion as they vie for the most support from the electorates by presenting arguments as to why they deserve the votes of the people and on the other hand the electorates sieve through the arguments which are to become policies and select the candidate whose policy positions best or closely depicts their own set of believes, expectations or preferences (Bratton, 2008). In that vein, any action that violates the electoral process can be classified as electoral fraud or malpractice and is considered an impediment to free and fair elections. Thus, any government produced from such a marred electoral process can be termed un-democratic. In the case of Nigeria, elections is seen as winner takes all scenario, requiring a fight to the death attitude and with such high stakes in play, there is no limit a politician would not go in order to secure votes be it fair or foul (Fafchamps and Vicente, 2013). That is why a lot of elections in Nigeria are marred with diverse methods of electoral malpractices such as electoral rigging, electoral violence include vote buying (Adamu et. al., 2016).

Vote buying is the direct exchange of benefit and material goods by the political elites to propel electoral support (Carreras and Irepoglu, 2013). It also includes buying of the voting shares or payments made to voters to influence them to vote for a specific candidate (Nichter, 2014). Election outcome in which vote buying is involved is slowly becoming normal way in which politics is played in growing democracies like Nigeria, having been transitioned from the military to the civilian era (Ovwasa, 2013). This is because the civilian administration aims to present an appearance of free and fair election, implement universal adult suffrage and following the electoral processes and Nigerian politicians make use of such desires through campaigning to manipulate the electoral rules by inducing material benefit to the electorate so as to acquire mass support (Bratton, 2008). 
Statement of the Problem

Election is a medium for the voice of the people to be heard. This has been norm as far back as the Greek city state where "show of hands" in support of a decision to be taken was carried out. Today elections have become a significant pillar of democracy and a means of legitimizing the decisions of government (David, Manu and Musa, 2014). In that vein, anything that is an impediment to elections, infringes on the ability of citizens to have their voice heard which affects an essential pillar of democracy (Adamu, Ocheni and Ibrahim, 2016). Nigeria the giant of Africa whose democracy and elections are closely watched by the international community; as a testimony of the growth of democracy and the possibility free and fair elections in the region, is still challenged with vote buying in its elections (Baidoo, Dankwa and Eshun, 2018). The presence of vote buying in Nigeria's elections especially that of 2018 Ekiti and osun state gubernatorial election as noised by INEC has raised some critical questions about the credibility of such election and her democracy (Akinkuotu, 2018). These questions include how free or fair can elections be when some candidates have bought the votes of the electorate even before the election? How can the principle of equality exist when vote buying gives more advantages to the wealthy over the poor? How responsible will the elected leaders be to the electorate when vote buying as an electoral transaction implies that the politicians have paid for the vote of the electorate? (Neeman and Orosel, 2008; Jensen and Justesen 2014; Adamu, et. al., 2016). The presence of vote buying in Nigeria's elections in addition to the questions raised, gives room for concern about 2018 governorship election in Ekiti state and the future of elections Nigeria. This research therefore, seeks to ascertain the presence of vote buying in the 2018 Governorship election in ekiti state, how truth are the question raised against vote buying in Ekiti state and what are the implications of vote buying to Nigeria's future elections and democracy focusing on Ekiti State .

\section{Objectives of the Research}

In accordance with the problem and research questions the overall objective of the research is to investigate the offshoot of vote buying on Ekiti State democratic elections. Specifically, the objectives are to:

- $\quad$ To examine the manifestations of Vote buying in the 2018 Governorship election in Ekiti state

- $\quad$ To determine the impact of Vote Buying on the 2018 Governorship election in Ekiti State?

- $\quad$ To ascertain the factors that encouraged vote buying in the 2018 Governorship election in Ekiti States

- $\quad$ To identify ways by which vote buying can be minimized in future elections in Ekiti State

\section{Research Hypothesis}

Some hypotheses were made in the null form to guide the research. These hypotheses are as follows:

- $\quad$ There were no manifestations of vote buying in 2018 Governorship election in Ekiti state

- Vote buying had no impact on the 2018 Governorship election in Ekiti State 
- $\quad$ There were no factors encouraging vote buying in 2018 Governorship election in Ekiti States

- Vote buying cannot be minimized in future election in Ekiti State

\section{Significance of the Research}

This research has three points of significance theoretical, governmental and statistical. Theoretically, the research on vote buying and democratic election using Ekiti state as a case study, aids in expanding the already existing literature on vote buying and Democratic elections in Nigeria. As the present literature review shows that there are limited studies done in Nigeria such as Bratton (2008) who examines Vote buying and Violence in Nigerian election campaigns, Ovwasa (2012) who examines Money Politics and Vote Buying in Nigeria: As the Bane of Good Governance. Governmental, this is necessary and significant as the present mode of election engineering carried out by political candidate creates an impediment to democratic elections and her growing democracy. Hence, exploring the nature, extent and effectiveness of irregular campaign methods such as vote buying is geminin to future elections. This research also throws light to who are the victims of vote buying in Nigeria with Ekiti state as a case study and what are the possible voter behaviors in responses to irregular campaign method like vote buying. Bratton (2008) explains that voter's behavior at the individual level when introduced to irregular campaign methods like vote buying can be classified into three possible course of action namely to refuse, to defect, or to comply. These three courses of actions are very important in understanding the outcome of the election in Ekiti state. The finding of the research offer valuable insight into how the government can tackle the issue of vote buying in future elections. Statistically, the research employs the T-test which is a great addition to previous studies both in Nigeria and other countries. Other studies have done relationship between electoral turnout and candidate popularity as a function of vote buying but the t-test exposes the degree at which the menace of vote buying has largely dogged into the fabrics of democratic elections in Nigeria.

\section{Scope of the Research}

This research focuses on five (5) local government areas in Ekiti state and the events leading to 2018 gubernatorial election until the 14th July 2018 the day for the gubernatorial election. The local government includes Oye (North), Ado Ekiti (Center), Ekiti West (West), Ekiti East (East) and Ikere (South). The choice of Governorship election in ekiti state is significant as it possess all the characteristics at a micro level to qualify it to be used as a research as well as statements from INEC about the presence of vote buying in the election.

\section{Limitations of the Research}

The challenges encountered in this research were mainly related to primary data gathering. The human factor which cannot be totally removed in form of biases, lack of total transparency and lack of willingness to release certain information that are vital to the research under the pretext classified information. Other issues include the scope of the research which is Governorship election in ekiti state as a case and making assertions about Nigeria as a whole. 


\section{Organization of the Research}

The research is divided into five chapters. Chapter one introduces the entire work, identifying the problem, objectives, significance of the research. Chapter two handles the literature review and theoretical framework. On the literature focus is placed on the subject of vote buying, democratic elections and the electoral process identifying the relevant concepts, issues and themes that are central to the research and for the theoretical framework adopted was the clientalism as it relates to elections. Chapter three handles the Research Methodology involving the Research Design, population of research, sample size, instrument of data collection, validity and reliability of the instrument Chapter four mainly covers the aspect of data collection, report/analysis. Chapter five concludes the research. It attempts a summation, and makes recommendations with the benefit of hindsight and field experience. The chapter thereafter makes a number of suggestions for future research

\section{Literature Review and Theoretical Framework}

\section{Conceptual Clarifications. Vote Buying}

Vote Buying like most social science concept lacks a universally accepted definition however; some similarities can be identified from the different definitions by scholars. However, the following definitions were adopted for this research; Vote buying is the provision of rewards to groups/individuals pre or during elections in lure of solidifying or changing voter's choice to their favor. These rewards could include cash, goods, service, position, kind or anything that benefits the said receiver in order to sway them over (Nichter, 2014). It is a form of clientelism known as political clientelism: which involves the direct/indirect exchange of vote for benefits by political elites before or during elections (Jensen and Justesen, 2014). Vote buying is also an economic transaction just like buying and selling of commodities such as shoes, bags and food stuffs based on demand and supply so as the electorates are willing to sell, candidates are also available to buy (Fredrick and Andrea's, 2005). It is interesting to note that vote buying cuts across all countries be it developed or developing countries the only different maybe in manifestation, level or magnitude. In Nigeria and most developing countries vote buying is closely related to an auction procedure were the highest bidder wins the vote. The most common exercise of vote buying in Nigeria can be seen during electoral campaigns when money and food stuff change hands to induce the electorate to vote for that party (Sakariyau, Aliu and Adamu, 2015).

\section{Approaches to Vote Buying}

Vote buying can be classified into two basic approaches (Adetoye, and Omilusi, 2016; Onuoha and Ojo, 2018).

Payment for Vote approach: This approach to vote buying is largely based on trust the buyer puts on the seller. In this situation the vote buyer mostly the agent of a party seeks out a prospective voter and they agree on a particular amount in the situation of cash or position or goods in the situation of kind. The transaction in payment for vote is done before the day of the election or on the Election Day and the location of the transaction can be around the area of the polling center or at any other location (Onuoha and Ojo, 2018). Adetoye, and Omilusi, (2016) argue that most times the vote buyer demand evidence of 
capability of the vote seller to vote such as been a registered voter with a voter's card and some form of assurance that the voter will keep their word and vote for their party before payment is done.

Vote for payment approach: This approach to vote buying is also dependent on trust but this time trust the vote seller puts on the buyer. In this situation payment is done either money or material benefit after evidence has been shown that the voter keep his/her word by voting for the agreed individual or the party (Onuoha and Ojo, 2018)

\section{Catalyst of vote buying}

Vote buying is a contemporary topic circulating around both the international and domestic community. However, it is important to determine what the catalyst that aids the progress and growth of Vote buying in New Democracies. Serval scholars have identified some catalyst aiding the progress of vote buying. Scholars like Bratton, (2008), Carreras and Irepoglu, (2013), Jensen and Justesen, (2014). This catalyst includes

1. Poverty: The place of poverty as a catalyst for vote buying cannot be overlook. When individuals can't access the basic necessities of life such as food, clothing and shelter and an opportunity to solve their need is provide with selling their vote as the price. That decision will be a no brainy transaction because they will sell their vote in a heartbeat without thinking about it. This reality is therefore, explored by candidates as they focus their vote buying strategy on the poorest of the electorates. Jensen and Justesen, (2014) explained that although vote buying is common, poverty makes some set of people to be targeted by vote buyer. Reasons for such include the number of individuals ready to sell their vote are higher towards poverty stricken members of the electorate. Secondly the cost of the vote is classified as cheaper amongst the poor.

2. Lack of trust in the government: this is another catalyst for vote buying as individuals who see government as not trust worthy or perceive that they are not likely to gain dividend from democracy will rather collect their own share of the national cake during electoral campaigns by selling their votes (Bratton, 2008).

3. Lack of voter's education and enlightenment: it is said that ignorance is bliss but a very dangerous bliss because of the side effect that come from lack of knowledge. This is another catalyst for vote buying as the electorates are mostly not aware of the magnified or consequence of their decision. Hence, they sell their future for a pot of porridge. Mmeyenne Jude the National Publicity Secretary of (RPN), speaking with Leadership Newspaper explains that vote buying is undoubtable an electoral fraud and the worse kind because the buyers do not just defraud by purchasing the conscience and present entitlement of the electorate but the future of their children for a plate of porridge compared to the enormous proceeds of democracy accrued to the them as citizens of the country (Oguntola, 2018).

4. The lack of operation of electoral laws and sanctions: This is another strong catalyst to vote buying because when individuals participate in vote buying and get away with it because sanctions are not implemented. Other people are motivated to do the same (Elekwa, 2008).

Leveraging on the works of the above scholars it is evident that a lot of literature has been done on the concept of vote buying, the nature of vote buying and some catalyst of vote buying. However, very little literature has been done on the effects of vote buying to credible elections and how vote buying threatens democracy especially in a budding 
democracy like Nigeria. This therefore, become the gap in knowledge in which this research intends to fill.

\section{Elections and Electoral Process}

Election a features of democracy can be said to be an indispensable characteristic of any democratic transition and the hallmark of democracy (Inokoba and Kumokor, 2011). This is because, it is during elections that the voices of the people are well heard and it is also recorded as an event with the highest rate of political participation by the people. Today elections are seen as the most acceptable medium by which citizens choose their leaders in an orderly, serene and peaceful exercise (Momoh, 2005). According to Dr Nwodo (2011) he explains that Election is what gives birth to the future not the stories of the past (Nnamani, 2014). This typically means that elections is a new opportunity to either correct or improve the events of the future taking lessons from the past and not living in them. Election is a new opportunity/avenue for citizens to indicate their choice amongst candidates, manifestoes, policies and programs presented to them by individuals vying for leadership positions (Ayeni-Akeke, 2008). Election is also an instruments for removing unpopular and ineffective leaders as well as forcing elected officials to hearken to the plight of the people, this because the people hold the power to the renewal or cancellation of the tenure of every elected official. These functions of election are made possible because of the provision of the electoral process; which spells out the method to be used in selecting individuals for political offices (Nnamani, 2014). Electoral process can be said to be the sum total of activities relating to carrying out an election, starting from as small as providing of voter education to as large as removing or installing a president. The concept of Electoral process has had a good share of voice from diver's scholars: Akamere (2001) expresses electoral process in terms of activities and procedures involved selecting representatives or leaders during an election by the electorates. It also involves the pre and post-election activities put in place to ensure the election run smoothly and be credible as without such the election may ended up void. Electoral process is also the stipulated method or process by which individuals are elected to public office in a democratic society. For an electoral process to be deemed free and fair as well as credible some agenda and provision most be put in place to aid the electorate, candidate and political parties harness effective the election to be conducted (Nnamani, 2014). In Nigeria the body that is saddled with the responsibility of determining the agenda and implementing the electoral process during elections is the Independent National Electoral Commission (INEC) which stipulates some stages or phrases during elections which include description of constituencies, registering political parties, registering qualified voters, recruitment of adhoc staff for the election, providing electoral material, announcing the stipulated time to commence election campaign, organizing debates between political parties, announcement of the election, conducting the election, broadcast of the results and the process of trial in the event of election disputes (Elekwa, 2008; David, et al. 2014)

Election campaign is a lawful and legal process available to all candidates vying for an elective office to sensitize, educate and convince the electorate on his party's manifesto, ideology and most importantly why such candidate should be given the opportunity to be trusted with their vote (Beyer, Knutsen and Rasch, 2014). Election campaign is a unique tool in the hands of candidates serving divers functions such as acquisition of voters need and expectation, selling of party policies and programmes to the 
people and real time record of citizens-voters problems from different regions with a view to the possibility of dealing with them (Grbeša, 2004). This is not the case in Nigeria as electoral campaign is used as a medium for expletives expression and debasing actions against the opposition as well as lavishing of ill-gotten wealth on the electorates with the intention of recouping such wealth via corruption. It been observed over time in Nigeria that this nature of election campaign has kept recurring and very successful because the voters are both not enlightened and illiterate as well as been bewildered by poverty (Jensen and Justesen, 2014).

\section{Implication of Vote Buying on Election}

Vote buying has serval implication of the election of any society, these implications affects different area of the election such as

Low participation in politics: vote buying affects the participation of both the electorate and the political candidates for contesting in election. On the side of the electorates when the voters believe that the election is already marred by vote buying, the impression that their vote does not count sets in and as such there is no need to vote. Carreras and Irepoglu (2013) explains that electorates who receive incentives (cash or kind) during the campaign are more likely to vote and individuals who do not believe in selling their votes see no reason to vote. This is because election participation is largely determine by how the election appears to the people; if the people believe that the election is unfair or corrupt, they have no incentive to participate or cast their votes as to them voting or not voting has no relevance on the outcome of the election (Franklin, 2004; Birch, 2010). To the aspiring leaders who intend to contest election, vote buying suggest that money rather than credibility, policies is what is required to win elections which becomes deterring element for good and trustworthy candidates contesting for office

Lack of trust in the government: Vote buying shows what extent a leader is willing to go to gain power, remain in power and have their way. When a candidate decides to buy votes as a medium of winning election, rather than winning fair and square, it shows that candidates disregard for democratic norms and the candidates willingness to use corrupt means and this in turn weakens the trust in the government (Neeman and Orosel, 2008). This is because if that candidate can use corrupt means to get into power, what stops them for using corrupt means to stay in power.

Low responsibility of leaders to the electorate vote buying as form of clienteles, see candidates as capitalist who make investment with the end game of making profit. Vote buying as an electoral transaction implies that the politicians have paid for the vote of the electorate and therefore, not responsible to them (Jensen and Justesen 2014; Adamu, Ocheni and Ibrahim, 2016).

Vote Buying and Election in Nigeria. Nigerian Elections since Independence focusing at the National Level

Nigeria got Independence in 1960 and in line with the political system during colonialism adopted a Westminster model of the parliamentary system of government (Dudley, 1982). The general election that got representatives into the local council, regional and federal legislature was conducted on December 12, 1959 using secret ballot system for voting. The electorate eligible to vote in Western and Eastern part of Nigeria consisted of all registered adult while in the Northern part of Nigeria; eligibility to vote was only give 
to registered adult males. The existing ethnic based parties which were the Northern People's Congress (NPC), National Council of Nigeria and Cameroons (NCNC) and Action Group (AG) came out as the dominant parties for the three regions. None of the three parties was able to make majority to form the government hence there was a need for a coalition government that was formed between the NPC and the NCNC making Tafawa Balewa as the Prime Minister and Chief (Dr.) Nnamdi Azikwe was made the chairman of the House of Senate by Sir James Robertson the Governor-General at the time (Dudley, 1982; Abia, 2006). Although, Nigeria got independence from Britain in 1960, the nation was still a Commonwealth Realm with Elizabeth II as titular head of state. After independence as a result of the flaws of the 1960 constitution, the spirit of nationalism and a desire to be totally freedom from our colonial masters Nigeria in 1963 adopted a new constitution declaring the nation a Republic, with a ceremonial President, Nnamdi Azikiwe who had assumed the role of a ceremonial Governor-General after independence (Abia, 2006). There was a discrepancies between the number of individuals eligible to vote on the voting rolls and the amount of people that live in the location based on the census resulting in the election been postponed for several weeks. Even at that UPGA still felt some fraudulent act been played and called for a boycott of the election by its supporters. The call for the boycott of the election was however, effective in the Eastern Region resulting in about fifty-one constituencies where polling unit existed not opening especially those units that had more than one candidate running for office. In a lot of other constituencies in the eastern region, UPGA candidates ran unopposed. This action and other had a ripple effect nationwide with only 4 million voters casting their votes, out of 15 million who were deemed eligible. From the 261 constituencies based on the result that was returned it was recorded that NNA was able to elect 198 candidates were 162 represented the NPC. As a result of the outcome of the election President Azikiwe reluctantly asked Tafawa Balewa to form a coalition government with the NNA majority. This action however, resulted in neutralized the effect of boycott on the election giving the party within the House of Representative a total of 108 seats. By March 1965 the Eastern Region and Lagos had supplementary elections conducted in areas where the boycott was successful. This however, favored the UPGA candidates as they were elected in all these constituencies making UPGA the official opposition to the ruling party (Dudley, 1982; Abia, 2006).

The interest of UPGA however, became focused on the legislative election which was to hold on November 1965 in the Western Region their plan was to be able to gain control over the three southern regions, Lagos and the region surrounding the capital. They believed that if that was successful it will give the predominant southern UPGA a majority in the Senate (Elaigwu 2005).

This plan was however, not successful, although been accused of massive voting irregularities, the NNDP recorded landslide victory in November, resulting in an outbreak of protest. This protest was not only recorded among the civilians but was also recorded among the senior army officials because of the vivid perversion of the democratic process. It was therefore, recorded that an estimated 2,000 people were killed because of the result in the six months after the election (Abia, 2006). This however, resulted in the instability of the country, this state necessitated the intervention of the military were army's commander Major General Johnson Aguiyi Ironsi stepped in to restore discipline within the army and the country. This however, coincided with President Azikiwe admission in a London hospital while he was undergoing treatment. The military takeover from civilian 
rule by Major General Johnson Aguiyi Ironsi sparked an effect of coups and counter coups and then a civil war and Military control of government unit 1975 (Dudley, 1982; Elaigwu, 2005). On July, 29, 1975 General Murtala Mohammed came into power after which he established a Constitution Drafting Committee (CDC) on October 18, 1975. Charging it with the responsibility of producing a new constitution for Nigeria, with a specific mandate of eliminating the existing constitutional problems in which Nigeria was facing. With this mandate at hand the committee performed extensive comparative reviews of constitutions and systems of government which involved them travelling to several countries so as to studied them in operation in order to come with appropriate form of government for Nigeria. After their research was over the committee submitted a draft which was studied and reviewed by a Constituent Assembly (CA). General Murtala Mohammed did not live long to see his vision of returning Nigeria back to a democratic dispensation however, his successor Lt. General Olusegun M.A. Obasanjo had that a reality. The journey to achieving this vision started with establishing the Constitution Drafting Committee (CDC) in 1975, to be constituted by 50 members Committee which eventually became 49 members because Chief Obafemi Awolowo opted out as a result of poor communication. The CDC was chaired by Chief Rotimi Williams a constitutional law guru and then the Constituent Assembly which was established in 1976. The constituent assembly chaired by Justice Udo Udoma was made up of 230 members composed of 190 indirectly elected and 40 Federal Military Government appointed members. The main aim of the assembly was to examine and ratify the drafted constitution of the Constitution Drafting Constitution. The constituent assembly identified some minor concerns in the drafted constitution and with the amendment those aspects the constitution was promulgated and came into effect on October 1, 1979. The dictates of the constitution ushered in Alhaji Shehu Shagari as the first Executive President of Nigeria (Abia, 2006; Oromareghake, 2013). That election wasn't devoid of allegations of election rigging and other malpractices the result however, was challenge in court by the UPN as it complained bitterly over rigging of the 1979 election. By 31st of December 1983 another coup was successful bring the military once more into power which lasted to the 1993 aborted third Republic; the presidential election of June 12, 1993 which was believed to be the freest and fairest in Nigerian elections since independence however, got cancelled by the Army over the failure of The National Electoral Commission (NEC) to abide by the ruling of the court to postpone the election as a result of the allegations made by Association for Better Nigeria (ABN) over the corrupt nomination of Chief M.K.O. Abiola (Oromareghake, 2013).

The 1999 general election that ushered in the fourth republic and was the election that finally disengaged the military from politics as usual had allegation of severe rigged and electoral malpractices (Osaghae, 1999). The allegations against the transparency of the 1999 election includes electoral materials shortage at the polling centers, pre thumb printed ballot papers and thumb printing of ballot papers on the election day outside polling centers, the result of election not in accordance with the electorates that came out to vote in different centers, etc. The All Peoples Party (APP) and Action for Democracy (AD) alliance both went to court to challenge the result which declared Olusegun Obasanjo the presidential candidate of the Peoples Democracy Party (PDP) as the winner. However, their efforts was fruitless as they lost making Olusegun Obasanjo the first president of Nigeria in the Fourth Republic (Oromareghake, 2013). The subsequent elections of both 2003 and 2007 elections also had accounts of worse electoral malpractices allegations against the 
both elections include snatching of ballot boxes from electoral officers and replacing them with already thumb printed ballot papers in favor of the ruling PDP was said to have taken place, double thumb printing so as to make ballot papers of the opposition parties void was alleged to have happened, some centers where election was never conducted because electoral officials failed to show up suddenly had results recorded for such centers. In some other centers through corroboration between electoral officials and party agents produced inflated and doctored results (Oromareghake, 2013). The two presidential elections of 2003 and 2007 had the incumbent President Olusegun Obasanjo return for his second term and President Musa Yar'Adua start his first time all from PDP. The 2011 election was a step forward towards better democracy as the election was the most transparent election since 1999, the election recorded a situation where vote were opening casted and recorded in the various polling booths. The 2011 election and its generally acceptable outcome was a spark that rekindled new hope for the future of democracy in Nigeria. It was more or less popular option that the 2011 election had moved Nigeria forward towards achieving electoral excellence, although there was much room for improvement which included refining the methods to make it more transparent. The transparency of the 2011 election made the number of litigations in the tribunals substantially reduced compared to other elections. However, the violence that followed gave the election a bitter taste as it was recorded that about 1000 lives were lost as a result of the violence (Osabiya, 2014).

The analysis of the election based on the two prominent parties and their presidential candidate incumbent President Goodluck Jonathan for PDP and Muhammadu Buhari for CPC shows Goodluck Jonathan winning, 59\% and Muhammadu Buhari winning 32\% (Animashaun, 2015). This was the win that made Goodluck Jonathan President for his first term after completing President Musa Yar'Adua tenure following his death in office. The 2015 election was a unique election and a testimonial of the growth of democracy in Nigeria, the election was special for several reason one of which was that the election was a build-up on the great stride achieved in 2011 and rematch between Goodluck Jonathan now the incumbent President of PDP and Muhammodu Buhari the Presidential candidate of APC (a merger of CPC and AD) (Uduak-Obong, and Forsberg, 2018). Another reason for the uniqueness of the election was that it showed the growth and characteristics of democracy where leaders are periodically required to test their popularity based on the support of the people, Goodluck Jonathan's administration had several challenges some of those challenges includes high level of corruption, high rate of unemployment, Boko Haram insurgency, etc. These challenges form the platform in which Buhari campaigned with his slogan "Change” (Olowojolu and Ake, 2015). Finally, the election also showed a significant nature to how politics is ran in Nigeria, which occurs following religious and ethnic affiliation. This was evident because the candidates were from two different parts of the country: Jonathan from the south and Buhari from the north. Jonathan got more support from states in the south-south, South-east, and parts of the South-west while Buhari got most of his support from the northern states and because APC was a merger between $\mathrm{CPC}$ and $\mathrm{AD}$ the remaining south west state where in support of Buhari This support for Buhari of Both the North and most of the South West made Buhari the winner of the 2015 presidential election (Uduak-Obong, and Forsberg, 2018). 
Vote Buying in Nigeria’s General Elections 1999-2018 at National Level

The return to civil rule in 1999 propelled great expectation of a speedy growth of democracy in the hearts of citizen; as the international community watched Nigeria closely to see progress especially on the aspect of free and fair elections and democratic leadership. (The Carter Center, 1999). However, that isn't the case as Nigerian government and leadership today still have a high degree of authoritarianism. Some may say perhaps it's because significant leaders of the fourth republic where former military men who only took off their uniforms but never became true civilians (AuwalAbubkar, MohdMahadee and $\mathrm{Ku}$ Hasnita, 2017). The major difference is that in the past the military men came into power without giving the people a choice or say in the matter about governing them but the present administration which is supposed to be a democratic administration have come into power having a resemblance of democracy and an appearance of free and fair election giving the people a choice of having the carrot or the stick. The carrot represented by vote buying or the stick which is electoral violence (Bratton, 2008). Vote buying in reality isn't a new phenomenon in Nigeria haven been in existence and practiced over the years in different elections since independence, although discreet (Sakariyau, Aliu and Adamu, 2015). The process of vote buying involved politicians and/or their agents appeared very close to the election date to give money, food stuff, opportunities and benefits in order to buy the votes of the electorates (Oguntola, 2018). The presence of vote buying runs through the entire process of Nigeria's election starting from the different party primaries, the party campaign activities, meeting with specific association and community development representative, up to the polling centers on election day (Owete, 2014; Olowojolu and Ake, 2015; Onuoha, and Ojo, 2018; Thomas-Odia, 2018).

\section{General Election and Vote Buying}

The 1998-1999 general elections were key elements in the return of power from the military to civilian rule. The death of General Abacha brought General Abdulsalam Abubakar into power, who started almost immediately on the process of transition Nigeria into a democratic government. General Abdulsalam Abubakar regime promulgated the 1999 Constitution through Decree No.24 of May, 1999. The 1999 Constitution made provision for multi-party system which were allowed to contest in every election in Nigeria as long as they meet the requirement of the INEC (Odusote, 2014). General Abubakar admitted that the plan to return Nigeria back to a civilian rule by his predecessor was nothing but political fraud and as such, he disbanded and dissolved the five political parties that were registered under the Abacha regime as well as their result from the election pronounced null and void based on lack of credibility. He also dissolved the National Electoral Commission established by the Abacha's regime and established a new electoral body called the Independent National Electoral Commission (INEC), which was headed by a retired Supreme Court judge Justice Ephraim Akpata. General Abubakar also promised not to interfere with party formation and allow the commission freely conduct their duties so as to convince the world of the commission independence and that the country has truly on the path towards democracy. The body was therefore, was charged with the responsibility of registering political parties, registration of voters and the conduct of elections. The registering of political parties had over fifty political associations emerging within a month but only thirty of them collected registration forms and by the end for submission only twenty-four of these associations had returned their forms. Based 
on the requirement by INEC only Nine out of the twenty-four political associations was able to meet the conditions for registration as a political party and therefore, given provisional registration as political parties. However, the local government election performance was a yardstick for confirmation of those political parties (The Carter center, 1999). The time table for the election was therefore, set for December 5, 1998 as the local elections; January 9, 1999 as the state and gubernatorial elections; the February 20, 1999 as the National Assembly elections; and February 27, 1999 as the presidential election. The local government council election was scheduled to Just as schedule to hold on December 5, 1998 and as part of the electoral guidelines stated, among others was that for any political party to be confirmed it had to score a minimum of five Percentage of the total number of votes in at least 24 states. The parties able to meet this requirement among other conditions and get confirmed were the (AD) Alliance for Democracy, (PDP) Peoples Democratic Party and (APP) All Peoples Party. These three political parties were given official complete registration by the (INEC) Independent National Electoral Commission (The Carter center, 1999; Odusote, 2014). The Local government result between the three fully registered parties showed that the People's Democratic Party had more chairmanship and councillorship seats and was more nationalist in nature having a wider geographical spread in terms of support than the remaining parties. This result also shows that the All Peoples Party (APP) was next in line in terms of chairmanship and councillorship seats but got most of its support from the northern party of the country (Odusote, 2014). The Alliance for Democracy $(\mathrm{AD})$ came third getting most of its support from the southwestern yourba speaking part of the country. The Gubernatorial and Houses of Assembly elections held on January 9, 1999 nationwide did not show much difference from the local government elections in relationship to the results. The People's Democratic Party (PDP) the only party at the time with a National outlook started with a lead in the gubernatorial election sweeping twenty one states, the All Peoples Party (APP), followed suit by winning nine Governorship seats from the north and the Alliance for Democracy (AD) had its dominates in the southwestern been able to sweep six states. The State Houses of Assembly Election was not different as the same arrangement in victory was also represented by the political parties, PDP taking the lead, APP coming next and then AD. After the State House of Assembly Election was concluded came the National Assembly election which held on the 20th of February, 1999. The result of the election followed the existing pattern with People's Democratic Party (PDP) establishing its lead, by sweeping sixty-nine (69) Senatorial seats and a majority seats in the House of Representatives election; the All Peoples Party (APP) came next by winning twenty-one (21) Senatorial seats and in the House of Representatives a good number of seats. The Alliance for Democracy (AD) came third been able to sweep nineteen (19) Senatorial seats and a few seats in the House of Representatives (Odusote, 2014). The AD victory included unexpected win of two seats both in the Senatorial and House of Representatives from Enugu State which happened to be a strong base of the People's Democratic Party in the east. As the February 27, 1999 presidential election drew nearer, it was obvious that the PDP was at the verge of having an easy win for any presidential candidate presented by the party as a result of their dominance in all previous elections (The Carter center, 1999). The AD and APP had no choice than to form an alliance to checkmate the popularity of PDP if they were to have any chance in the presidential election. When AD and APP found out that General Olusegun Obasanjo (Rtd) from the south west, was selected as the presidential flag bearer 
of PDP, Chief Olu Falae of the AD was selected as the joint presidential candidate of both (APP) (AD) to checkmate the move of the PDP. The choice of picking Olusegun Obasanjo from Ogun by the PDP and Chief Olu Falae from Ondo by the AD-APP coalition which recorded the first time in history were both presidential candidates will be coming from the same region could be linked to the June 121993 election which Chief M.K.O. Abiola, claimed to have won both was cancelled. The aftermath of the cancellation and the actions of M.K.O Abiola resulted in him been detained and eventually dying in detention. This gesture however, could be said to be an attempt to appease the South-west who at that time claimed to have been cheated by the North since the Head of State at that time was a Northerner (The Carter center, 1999).

On February 27, 1999 Presidential election

The total number of registered voters: $\quad$ 57,938,945

The total number votes turned in: $\quad 30,280,052$

Percentage of Registered Voters: $\quad 52.3 \%$

The Invalid/Blank votes: 431,611,

Total valid votes: $\quad 29,848,441$.

Chief Falae immediately reacted to the result by calling the entire process nothing but a farce and announced his intention to challenge the result in court (Odusote, 2014). In a special report by the Carter center (1999) while observing the Nigeria's 1998-1999 election discovered that during the electoral campaign "big money politics" backed up financial patrons shaped the whole election starting from the party primaries, to the electoral campaign and the actual election. The delegates of the center heard and observed wide spread bribery of voters, electoral agents and officials transition, particularly in the latter voting rounds. One of the submissions of the report was that in an environment of severe poverty, the temptation is magnified for the electorates to sell their votes and the money bags are very willing to take that opportunity to buy.

\section{General Election and Vote Buying}

The 2003 April general elections was a unique time in Nigerian democracy a country that has had to endure failed experience moving from one democratic government to another. Based on past events the political transition has mostly been from a civilian administration to a military regime rather than from one elected civilian administration to another. Thus, the April 2003 presidential election was to be both a change in history and first of its kind in over 20 years (Nwokeke and Jayum, 2011). In preparation for the election, an addition of twenty-seven political parties where registered by INEC in addition to the three already registered bringing the total number of political parties to thirty eligible to contest in the elections. Although, most of these parties were those that failed in meeting the requirement and as such denied registration by INEC before the 1999 elections (Ogbeidi, 2010). The pre-election activities got the outcry of the public especially on the subject donations by politicians and corporate entities, the Nigerian public described those donations as unconstitutional and fraudulent. Some of this donations includes N5.5 billion realized by President Olusegun Obasanjo and his Deputy, Alhaji Abubakar Atiku raised during their campaign, N2 billion raised by Chief James Ibori Governor of Delta State, N1.3 billion raised by Chief Bola Ahmed Tinubu Governor of Lagos State raised (Human Rights Watch, 2004). The schedule for the elections was slated as April 12, 2003 for The National Assembly election, April 19, 2003 for the Presidential and Gubernatorial election 
and May 3, 2003 for the State House of Assembly. The Election on April 12, recorded an overwhelming number of voters in most polling centers, the process of the election moved smoothly in some polling center while in some it was practically nonexistence as a result of either vote-rigging or violent intimidation or a combination of the two and other polling centers had logistical problems that impeded the smooth running of the elections giving some parties agents and candidates opportunity to falsify results (Nwokeke and Jayum, 2011). On April 15, 2003 with a nemine contradicente nine registered parties agreed to reject the result of the National Assembly polls. These parties included (NDP), (UNPP), (APLP), (NNPP), (JP), (PAC), (APGA),(ARP) (CPN) (Ogbeidi, 2010).

By April 19 which was the Presidential and Gubernatorial election several incident of violence had occurred with identical presence of voters and problems encountered on April 12, even though for some locations election never occurred because of challenges of elections materials getting to the polling center or absence of the election officials however, when the results were officially announced such locations got result from these constituencies (Moshood, 2009).

The April 19, 2003 Presidential Election

The total number of registered voters: $\quad 60,823,022$

The total number votes turned in: $\quad 42,018,735$

Percentage of Registered Voters: $\quad 69.1 \%$

The Invalid/Blank votes: 2,538,246,

Total valid votes: $\quad 39,480,489$.

By May 3, the efforts of the violence has ran its course as trust and morale in the election had dropped as must opposition party members especially in south and the southeast started boycotting the election and advising voters not to wait their time casting useless votes. The public outcry against the election and its results included electoral rigging, electoral fraud, political intimidation and assassination etc. In the final report of the Transition Monitoring Group (TMG) on the elections, TMG described the 2003 election and the result announced as an election characterized by monumental fraud (Transition Monitoring Group, 2003; Moshood, 2009). The 2003 election saw the PDP returning President Olusegun Obasanjo as the president for the second term, increasing its seats at the national legislature and winning more gubernatorial positions at the state level. The result of the 2003 election was contested by several associations and groups such as the Patriots led by the late Chief F. R. A. Williams, the Civil Liberties Organization (CLO) and so on. These groups and associations called for the cancellation of the result and suggestion for an interim government while elections are reran and a national conference so as to tackle the bewildering challenging's of the Nigeria State and Democracy (Ogbeidi, 2010). The presidential candidate of the All Nigeria People's Party and former military Head of state General Mohammed Buhari (Rtd.) in protest to the result threatened to make the country ungovernable if the results of the general elections of April and May 2003 were not cancelled and another election conducted. Alhaji Umaru Sada Ndayako leading a group of Northern leaders presented President Olusegun Obasanjo with a list of conditions to prevent a clear state of emergency in the country as a result of the rejection of the April election by over sixteen opposition parties led by the ANPP (Ogbeidi, 2010).

The European Union Election Observer Mission (EUEOM) observing the 2003 election discovered new information confirming the irregularities within the election and 
challenged result and conduct of the election (European Commission, 2003). In a report by the mission they noted that the elections in Kaduna, Rivers, Cross River, Edo, Delta, Imo and Enugu States were marred by serious irregularities. The Head of the observer team, Mr. Max Van dem Berg reported cases about arrest of opposition candidates shortly before the May 3 elections with an example of Edo State (European Commission, 2003; Iyayi, 2005). The 2003 election had little evidence of vote buying which occurred in the electoral campaign in form of distribution of commodity and food stuff. However, there was high rate of electoral violence, intimidation, electoral fraud and assassination.

\section{General Election and Vote Buying}

The 2007 election was hoped as an election to consolidate the existence of democracy in Nigeria. In other to tackle the flaws of 2003 election and to make 2007 election free and fair, the Independent National Electoral Commission (INEC) called meetings in December 2003 and February 2004 consisting of government agencies, civil society organization, political parties and the electoral commission to figure out a way forward in achieving their goal. The result of the meeting identified four critical obstacles that needed solution on or before 2005 so as to make the 2007 election free and fair. (Ibrahim, 2007; Nwokeke and Jayum, 2011).These obstacles included

Real autonomy of INEC: Participates in the meeting believed that only when INEC was truly autonomous was there going to be a resemblance of free and fair election. The consensus of participates of the meeting that the power in which the president had over key officers of INEC such as the chairman, national commissioners, and resident state electoral officers as a result of been appointed by the president needed to be taken away. In addition, participates of the meeting believed that it was necessary for provision to be made to prevent the executive from starving Independent National Electoral Commission from getting the necessary funds to able it perform. Therefore, it was proposed that INEC financing should come directly from the consolidated revenue fund.

The Revision of the Electoral Bill: participates in the meeting also believed that some aspect of the Electoral Act of 2002 which had been identified and improvement should be passed into law. One significant aspect was the improvement which imposed a limit on campaign expenditure by political parties. This law was finally enacted in June 2006.

The completion and updating of voter registration used for the 2003 elections: it was observed that the voters registration used for the 2003 was incomplete and as such many eligible voters' names were not on the voters list. It was therefore; decided that INEC should put mechanism in place for continuous registration according to the provisions of the Electoral Act which will aid the registration of individuals that were omitted in the previous registration and those that have come of age since 2003.

The distributing new voter identity cards expected to be use in the election: it was observed that the process of distributing the permanent voter's card which was to have embossed photographs and biometric features that commenced about three years ago was yet to reach the people as less than $40 \%$ of the electorate had received theirs (Ibrahim, 2007).

As the 2007 election draw nearer it was obvious that INEC was not taking heed to implementing the necessary requirement in order to achieve free and fair elections in 2007. This was obvious because as at September 2006 which was few months to the elections, the process of voter registration had not yet kick started except for the trial run that was done in the Federal Capital Territory (Nwokeke and Jayum, 2011). This raised some 
concern as it looked like INEC was banking on a hurried and unorganized method towards the registering of voters which further aroused suspicion about the possibility of individual's planning on preventing the 2007 election from holding or if held be a failed one at best. This fear and suspicion was further strengthen by the actions of the chairman of INEC Maurice Iwu during his first year in office, as Iwu held the electoral preparation process hostage based on the argument that for the 2007 Election to hold the Independent National Electoral Commission had to use electronic voting machines. Observers and the citizen were flummoxed because regardless of the advantages the voting machines brought if it was to be use, at was not enough reason to impeded the election because the time needed for the legal procedures, constitutional procedures and a test run for a voting machine that meet Nigeria needs was not available and as INEC was focusing on achieving voting machines at all cost it was neglecting its basic duties in preparations of the elections, knowing that a timeline for all the various event and element had be set. Critiques and the opposition parties therefore, concluded that the reason that INEC is handling the matters of the election in a languorous manner had to be related to the ambitious third-term agenda of President Olusegun Obasanjo (Ibrahim, 2007).

On the political terrain, there was heightened political tension on one hand President Obasanjo and his vice Atiku were at odds as they accused each other of corruption while on the other hand the southern politicians were agitating for more tenures and northern politicians insist that power must move back to their North. These issues were coinciding with the continuous agitation by the militants of the Niger Delta over the control some oil wells located in their states (Nwokeke and Jayum, 2011). The 2007 election was scheduled to hold on April 14, 2007 for the gubernatorial election and state house of assembly election and April 21, 2007 for Presidential and National Assembly election

Many political parties got registered with various presidential aspirants perpetrating all forms of maneuvers in the struggle to dethrone the leadership of Peoples Democratic Party (PDP). Party primaries to provide candidates for the different positions occurred in late 2006; the internal debate concerning geographic rotation of power to the different arm of government rocked a lot of parties especially the PDP. After the failure of President Obasanjo third term agenda, on December 17, 2006, the PDP conducted voting to select its presidential candidate, although the exercise could not be called voting as several of the leading candidates were forced to stand down because of intimidation, threat and money politics so as to favor President Obasanjo's hand- picked successor the then-Governor Umaru Yar'Adua. This occurrence in the PDP convention resulted in a lot of politicians decamped to some other political parties. The primaries for the selection of the presidential candidate for other parties included the announcement of consensus candidates in some and the endorsement of allied parties' presidential candidates in others (Nwokeke and Jayum, 2011).

April 14, 2007 the day for the gubernatorial and House of Assembly elections it was observed that voting started late in several polling centers as a result of problems with the voter registry, shortage of electoral materials and the omission of candidates' names and/or photographs on the ballot papers. In some states, poll workers recruited failed to show up hence others were recruited on the post with little or no training. The election turnout was moderate in some location and poor in others however, there was incidences of sporadic outbreaks of violence, electoral malpractice including vote buying, electoral rigging and ballot snatching in several centers such as Ekiti State, Ogun State, Rivers State, Delta State 
to mention a few. The announcement of the result by INEC in favor of PDP in some state that was at odds with the expectation of the electorate resulted in outbreak of violence, killings and destruction of properties (Ibrahim, 2007).

On April 21, 2007 the day for the Presidential and National Assembly election due to administrative problems it was announced that the election should commence at $10 \mathrm{am}$ Nationwide however, it was noticed that the polls opened after 10:00 a.m. in almost every part of the country, and in some places did not open at all. This situation raised new wave of aggression and violence during the election (Ibrahim, 2007).

The April 21, 2007 Presidential Election

The total number of registered voters: $\quad 61,567,036$

The total number votes turned in: $\quad 35,708,880$

Percentage of Registered Voters: $\quad 58 \%$

Total valid votes:

35,397,517.

Based on the result the 2007 election Umaru Musa Yar'Adua was declared the winner and the next President of Nigeria. The presidential and gubernatorial election raised a lot of dispute as candidates contested the result of the election in the tribunals and the court. The election was classified by observers as the election with the most electoral malpractice in Nigeria history (Nwokeke and Jayum, 2011). In spite of the promise of free and fair election by INEC chairman, the local and international monitoring team categorized the election as one of the worse election conducted anywhere in the world. The April 2007 general elections set a new benchmark as it relates to electoral malpractice, far higher than that of 2003 and 2004 elections in the level of vote buying, electoral violence, rigging, electoral fraud, and complicity by the various organs of the state in the electoral farce that occurred. The record of electoral violence shows that over 200 individuals lost their lives nationwide during the 2007 election (Ibrahim, 2007; Nwokeke and Jayum, 2011)

\section{General Election and Vote Buying}

The road to the 2011 election could be traced to the dissatisfaction and condemnation of the 2007 general elections which was reflected by the amount of cases that was brought before the courts and the election tribunals as well as the amount of election results that had to be nullified (INEC 2007, Ugochukwu 2009). This therefore, necessitated for better plans and amendment to be put in place in order to achieve free and fair election 2011. Two major remedial measures taken by both the government and the Independent National Electoral Commission (INEC) to prevent the repeat failure of the 2007 general elections in 2011 was one the appointed Professor Attahiru Jega, a respected academic and activist as the chairman of INEC by President Goodluck Jonathan and two the revision of the 1999 Constitution and Electoral Act concerning the legal framework of elections in Nigeria. The confidence of the public in INEC was largely boosted at the appointment of Professor Jega as the INEC Chairman. The federal government promised to release funds adequately and in a timely fashion to aid the Commission to operate effectively to that end, 87 billion naira was released to INEC to aid its preparation for the 2011 elections (Gberie 2011). In a bid to achieve the success of the 2011 election INEC took some radical decisions which included creating a new voters register because the old one was alleged faulty which needed to be completed within four months. INEC also went decided to recruit National Youth Service Corps (NYSC) member and federal universities staff as ad hoc staff to register electorates and for the Election Day. This decision was taken 
to strengthen its election personnel. The 2011 election was initially supposed to be in January 2011 however, it was rescheduled to April 2rd, 9th and 16th but as a result of logistical problem and the desire for fair election it was further postponed to 9th for the National Assembly elections, 16th for the Presidential election and 26th for the Gubernatorial and State house of Assembly election.

The April 9 elections for the National Assembly had a lot of police security presence at polling stations; this was as a result of a bomb that went off in western region of Nigeria on April 8. The polling centers in almost all the locations opened by 8 am and just alittle later with the voting exercise going smoothly. The accreditation of voters started in earnest although there was a misunderstanding in most polls causing the turnout of voters were rather lower because the electorates assumed that the previous accreditation process done a week before will still be valid resulting to a large amount of electorate not able to vote in the election (Nwokeke and Jayum, 2011). Some other challenges where noticed in the April 9th election such as lack of privacy for the electorate, underage voters attempting to cast their votes. Regardless of the short coming of the process the election went smoothly and relatively fair (Gberie 2011).

The April 16 election had a lot of improvement in relations to the April 9 election. Almost all polling centers opened on time or with little or no delays and voter turnout was far higher than that of the previous election. The election had voters from young to old and women to men, the disabled, elderly and even pregnant women coming to vote (Gberie 2011). The atmosphere in most polling centers was calm and many people stayed back even after the polls had closed to observe the vote tabulation. However, some shortfalls were still associated with the election such as late arrival of INEC officials and election materials in some locations, inability to accreditation voters in some location, ballot-box stuffing, suspicious actions during vote tabulation, and so on. Nevertheless, the election in total had a good resemblance of been free and fair with little or no record of violence during the election.

The April 16, 2011 Presidential Election

The total number of registered voters: $\quad 73,528,040$

The total number votes turned in: $\quad 39,469,484$

Percentage of Registered Voters: $\quad 53.7 \%$

Total Invalid/Blank Votes: 1,259,506

Total valid votes: $\quad 38,209,978$

The announcement of Goodluck Jonathan as the winner and President of Nigeria defeating Muhammadu Buhari, with a 27 Percentage margin, resulted in an outbreak violence in places like Kano, Kaduna, and 10 other northern states between supporters of the Goodluck Jonathan and Muhammadu Buhari and between Christians and Muslims. The outbreak of violence claimed more than 800 killed with thousands injured and over 65,000 displaced, as well as damage and destruction to homes and property. The postelection violence tainted the election of April 162011 as one of the worst episodes of violence in Nigeria's recent democratic history (Nwokeke and Jayum, 2011). The April 2011 election was classified as the most free and fair election since the return of Democracy in 1999 however, the sudden outbreak of violence after the presidential election also tainted the victory and efforts put by both the government and the Independent National Electoral Commission (Bamgbose, 2012). From the different records gotten about the 2011 there 
was little evidence of vote buying on the days of election but during the electoral campaign of different parties and during the party primaries among the delegates

\section{General Election and Vote Buying}

The road to the 2015 general elections was a build on the success of the 2011 election. The 2011 election was a unique election first because in it was the first time in which Dr. Goodluck Jonathan was standing on his own for election as the main candidate since his political career commenced and winning to be the first individual from the Niger Delta region that will emerge as the executive president of Nigeria and secondly because it was the election with the worse account of post electoral violence (Olowojolu and Ake, 2015). The outburst of violence in 2011 created fear and anxiety both in the minds of local and international bodies about the possibility of Nigeria bursting in flames after the upcoming 2015 election (Orji and Uzodi, 2012). Prof. Bolaji Akinyemi a former Minister of Foreign Affairs appealed to both candidate which were President Goodluck Jonathan and General Muhammadu Buhari to sign a Memorandum of Understanding (MOU) the need for that sign memorandum of understanding was to help prevent the possibility of an outbreak of violence as a result of a loss from one of the candidate. The agreement stated that both individuals should speak to their supporters that if Jonathan the presidential candidate for the the Peoples' Democratic Party (PDP) should loss the Niger Delta militants could decide to resort to violence and if Buhari the presidential candidate of All Progressives Congress (APC) should loses the election, there will be another outburst of violence in the north hence both candidates to undertake a civil and peaceful campaign, devoid of threats (The Cable, 2014). The timetable for the presidential election was stipulated for February 14, 2015 while the governorship and state legislative elections was to hold on February 21, 2015. However, it was later postponed to March 282015 and April 11,2015 respectively as a result of security and administrative reasons. The 2011 Amended Electoral Act, which INEC relied upon in issuing the time-table, stipulates that campaigns into elective offices must begin 90 days to Election Day and end 24 hours before the election; meaning that the earliest time for campaigning to commence was on November 15, 2014 and end on February 12, 2015, which is 24 hours before the end of the 90 days stipulated in the Act (Daniel and Agbakwuru, 2014). The People's Democratic Party (PDP) had their two-day National Convention on the 10th and 11th of December, 2014 at Eagles Square, Abuja. Top on the agendsa of the convention was the ratification of President Goodluck Jonathan as the party's presidential candidate in the February 14th presidential election and that of Adamu Mu'azu and Wale Oladipo as the party's national chairman and national secretary, respectively. Over 3,050 delegates from the 36 states and the Federal Capital Territory were in attendance of the convention. The incumbent president was the sole presidential candidate for the PDP after the two opposition candidate Jelil Tafawa Balewa, son of Nigeria's former Prime Minister, and Akasoba Duke-Abiola, widow of the late Moshood Abiola withdraw from the contest (Owete, 2014).

The APC also held their primaries on the 10th of December, 2014 at Teslim Balogun Stadium in Lagos to pick the party's flag-bearer for the February 14 presidential election. The attendance of delegates at the stadium was estimated at about 8,000. The APC presidential aspirants included Atiku Abubakar the former Vice President of Nigeria under President Olusegun Obasanjo; Muhammadu Buhari former Military Head of State; Rabi'u Kwankwaso Governor of Kano State; Rochas Okorocha Governor of Imo State and the 
founder of Leadership newspapers and finally Sam Nda-Isaiah (Owete, 2014). The five aspirants were made to sign an undertaken that they will not fight the outcome of the primary as well as that the losers will not only strongly support the winner and the party but that they will not defect to another party. The results of the primaries were as follows Muhammadu Buhari: 3,430 votes, Dr Rabiu Kwankwanso: 974, Atiku Abubakar: 954, Owelle Rochas Okorocha: 624, Sam Nda-Isaiah: 10 votes and 16 voided votes were recorded (Owete, 2014). The behavior of vote buying within the APC primaries was evident between Muhammadu Buhari and Atiku Abubakar. It was reported that almost all the 8000 delegates who participated allegedly made US\$5 000 from both of the candidates. The Atiku Abubakar group was said to have given all the Delegates US\$2 000 each and the Buhari group was said to have given all the delegates US\$3 000 each. Given that the estimated number of delegates who were reported to have attended the primaries was 8 000, the estimated amount spent by both parties was US\$16 million and US\$24 million respectively on vote buying at the primary stage (Onuoha, and Ojo, 2018). Buhari with this victory moved on to be the presidential candidate for the APC in 2015 general election.

The Election Campaigns for the 2015 according to the provision of the electoral act started on the 15th of November 2014 with a lot of large-scale rallies in diver's locations in the different states in Nigeria. There were also a lot of campaigns using the media, especially social media. The 2015 election campaigns as usual did not anchor on high-minded political discus of policy proposals but low politics of promises and criticism of the opposition. The two main parties PDP and APC adopted mainly negative campaign tactics involving attack of opponent candidates and prominent party members. The PDP's main line of attack on Buhari was on his credentials and ability to contest for the presidency. The party tried to show a demarcation between the former military leader General Buhari and President Jonathan's in experience, education achievement (Orji, 2015). The was a fight for popularity and the minds of the electorate on the internet using young individuals especially with social media to attack rivals online by deliberately peddling misinformation and manipulating the electoral climate (Nwaubani 2014). The APC however, were clearly more coordinated, catchy and consistent in their campaign as the party anchored its campaign on the message of CHANGE which was a direct challenge to PDP's hegemony in Nigeria politics which they have had for nearly two decade long. The change message highlighted the shortcoming of the PDP lead government especially in the aspects of security and the fight against corruption, the change message carried by the youth, the middle and lower classes echoed all through society as APC described corruption as the greatest challenge impeding the government ability to produce results which happened to be fundamental nature of PDP. The APC haven established that foundation attacked the credibility of PDP as a party and the effectiveness of its government. The APC accused the PDP of only attending to the needs of the elite but presented the APC to be a party that carted for the needs of the masses and was ready to be accountable and responsible to their needs in education, employment, security, and so (Orji, 2015).

The March 28 presidential election was quite successful however, the process of voting process and the environment in Nigeria is faced with divers challenges these challenges include inadequate infrastructure, grave insecurity, unenlightened voters and power deadly contest for political power, these challenges inevitability affect the success and administration hereby causing hitches and problems during the election in the country. Some of these hitches include problematic Smart Card Readers and issues with the arrival 
of the election materials. The Independent Electoral Commission introduced a two-step voter-accreditation process which was to be used for the 2015 general election; these included the card-reading machines and the fingerprint authentication. The first was to ensure that the voter card was issued by INEC and the second step was to verify that the cardholder was truly the owner of the voter cards through their fingerprints (Orji, 2015).

The 2015 Presidential Election

The total number of registered voters:

$67,422,005$

The total number votes turned in:

$30,276,602$

Total Invalid/Blank Votes:

844,519

Total valid votes:

29,432,083

On 11 April, the day of the gubernatorial and House of Assembly elections, election management had gotten a lot of improvement, especially in terms of arrival of INEC official, opening of polling centers and functionality of the card readers. It was observed that nearly 90 per cent of the polling units opened on time and that accreditation process went smoothly with the card readers functioning with minimal hitches (Vanguard, 2015). However, the improvement gained was further marred by reports of fraudulent incidents such as intimidation of poll officials, interference with the result-collation process and snatching of ballot boxes. The cause of violence further escalated during the gubernatorial and House of Assembly elections reports of at least 30 people killed in 28 incidents. This number of killing surpassed that of the Presidential and National Assembly elections which was reported at 19 deaths in 20 violent incidents (Orji, 2015). The results announced by the INEC showed that APC greatly increased the number of gubernatorial positions, and won a majority of the seats in state and federal legislatures. The analyses of the election show PDP got massive support of votes from the South-South and South East while the APC swept the North West and North East. The 2015 elections recorded the long awaited victory of Muhammadu Buhari after standing for election in four successive times as well as a great victory for the APC (Vanguard, 2015). The 2015 election was indeed a win for democracy in Nigeria for the first time an incumbent president was defeated at the poll and transition without an outbreak of violence. However, the election was greatly affected by vote buying like some elections in Nigeria. In a survey carried out by Matenga, (2016) for his article titled, "Cash for Votes: Political legitimacy in Nigeria”, Nearly 80 per cent of the respondent acknowledge that voters at one time or the other got bribed during elections and only five to six cent of the voters believe that bribing for vote doesn't happen. In a longitudinal survey from 2007-2017, recorded that in 2007 seven out of ten vote strongly agreed that vote-buying was an recurrent event by 2016 almost a decade later, the number increase to nine out of ten respondent acknowledged witnessing a vote transaction request either from them personally or seeing others been persuaded (cited in Ojo, 2018). This however, can said to be a chronic problem for Nigeria's electoral process and democracy. Vote-buying in Nigeria most recent election conducted has escalated to the point that vote buying patrons go as far as giving money to election officials, security agencies, election observers and even the media to ensure success of their enterprise. Eye witness encounters from journalist and the observers reveal that at some polling centers, party officials enticed voters with cash ranging from N4, 000 to N10, 000 in order to get them to vote for a particular candidate however, they were to come with prove of voting for the agreed candidate to redeem their cash. (Thomas-Odia, 2018) 
This alarming phenomenon has made elections become an auction trade where victory goes to the highest bidder. Therefore, heightening the rate of political corruption because political office becomes a business investment and profit is the sole purpose of every business endeavor which they get back bountiful through corrupt avenues (Oguntola, 2018).

Vote buying as a crime in Nigeria

According to the Electoral Act, 2010, Article 130,

"A person who - (a) comuptly by himself or by any other person at any time after the date of an election has been announced, directly or indirectly gives or provides or pays money to or for any person for the purpose of comptly influencing that person or any other person to vote or refrain from voting at such election, or on account of such person or any other person having voted or refrained from voting at such election; or (b) being a voter, comuptly accepts or takes money or any other inducement during any of the period statedin paragraph (a) of this section, commits an offence and is liable on conviction to a fine of $\mathrm{N} 100,000$ or 12 months imprisonment or both." (Electoral Act, 2010:60 amended)

This explains that vote buying is a crime and every criminal action should not be allowed. The National Electoral Commissioner in charge of South-West, Mr. Adedeji Soyebi explained that although vote buying falls under electoral offence it should be further emphasized and highlighted as a capital criminal offence in order to curb the practice. He further elucidated that vote buying was not just an offence against democracy but an offences against humanity because it literally means buying the conscience of the electorate (Oyenigbehin, 2018).

\section{Theoretical Framework: Clientelism}

Clientelism theory explains the system of patron-broker-client ties and networks that operates within the politics and government of different societies (Piattoni, 2001). The theory has its tentacles in Economics and Political Science explains the transactions between politicians and citizens whereby material favors are offered in return for political support at the polls (Eisenstadt and Lemarchand, 1981). Clientelism has its origin traced to ancient Rome were the relationships between the patron (patronus) and client (cliens) were seen as crucial in understanding the political process. This kind of clientelism also known as old clientelism or notable clientelism has been likened to feudalism by Lemarchand and Legg although modern French historians such as Mousnier and Major disagree explaining that clientelism patron-client bond only had a feudal legacy, because there was no oath of homage and no exchange of fiefs in the patron-client bond; choice of master was free; and services were not defined (Eisenstadt and Lemarchand, 1981; Piattoni, 2001). Development of the theory evolved through the English industrialization and French revolution where the patron-client relationship was seen as a personal direct exchange in which on one hand the patron uses resources in which he owns or controls for the behalf of his clients (Parisi and Pasquino 1979). This involved assisting, defending and protecting 
his clients, by giving them material benefits and an opportunity for career advancement while the clientage on the other hand, was loyal giving the services that is owed to the patron in return for his protection and advancement (Katz 1986). A patron-broker-client relationship is a three-party transaction the patron who is the master that requires loyality, the broker who acts as a middleman or connector that arranges the exchange of resources between two parties separated by situations such as geo-graphic or personal distance such as differences in rank or office and the client who needs protection or favor (Piattoni, 2001). The theory of clientelism was further expanded by social scientists like Eisenstadt and Roniger, Lande, Brown and Schmidt the different social scientist identified that the changing structures of the state and society also affect the process of clientelism. Eisenstadt and Roniger explained that different systems affect the process of clientelism and it is largely dependent of social setting. Lande explains that variation in patron-client relationships are the result of variations in the substructure to which they are attached. Brown has observed that vertical clientelist power relations have changed over time and in respect to the structure of the state. Schmidt further elucidate that changes in clientage is usually as a result of changes in the larger society (Tarrow, 1967; Weingrod, 1968; Eisenstadt and Lemarchand, 1981).

Notables clientelism or Old clientelism existed to see modern democratic era in different parts of the world, in this contexts patrons, or their agents, stand for election and their clients vote for them, usually as a result of obligation, loyalty or because of what they tend to gain in good or services either already rendered or promised. However as a result of change in time and society this form of clientelism has evolved to the new clientelism which was first noticed in studies on postwar Italy (Tarrow, 1967; Weingrod, 1968; Caciagli and Belloni, 1981). These changes in society involved the replacement of landlords with organized political parties with structured party system as patrons; the clients on the other hand became electorates who demanded better and more immediate material benefits in exchange for their votes. In the change that brought about new clientelism, patrons had to 'buy' votes by distributing concrete excludable benefits and favours to individual voters or groups of voters (Parisi and Pasquino 1979; Katz 1986). New clientelism as an evolution of the old still shared some fundamental features such as the relationship between the patron and client remained mutually beneficial and the benefits provided to clients was still privately own or public materials controlled by the patron, which the patron rewarded the client from. Some differences also exist such as: the relationship in old clientelism was less hierarchical, while in new clientelism more democratic, the client were less bound to the patron and therefore, can use their vote in exchange for their maximum satisfaction (Parisi and Pasquino 1979; Eisenstadt and Lemarchand, 1981; Katz 1986).

The economic aspect of clientelism can be seen as a market exchange which is influenced by the forces of demand and supply. Based on this context the patron and the client interact with the sole purpose of maximizing utility as they jettison every sense of obligation towards each other. Economic aspect of clientelism does not focus on permanent relationship and the benefit provided by the patron to the client but is determined by the value provided by the client. The determinate of the benefit provided by the patron include how much other patrons intend to pay the client for their votes and the availability or scarcity of good that is individuals ready to sell their votes (Gellner, and Waterbury, 1977). 


\section{Application of the Theory}

Clientelism is germane in understanding how vote buying and elections in Nigeria. According to the theory Nigeria as any society within the modern day democracy is made up by patrons representing organized political parties with structures who are controlled by the political elite, these patrons during elections need the votes of the electorate which represent the client however, sometimes the patron are too far to reach the clients which therefore, requires an intermediary representing the brokers who come to speak or convince the clients to vote for the patrons. The theory also helps us to understand that the clients in the new clientalism does not need to be loyal to the party they are been influenced to vote for as long as the benefit expected from the patron or party is met, if such benefit dries up they can move over to another patron. The theory new clientelism helps us to understand that the good provided to the client does not necessary need to be private good only but public good like government position, favourable government policy and so on controlled by the patron. It also helps us to understand that the support of the clients does not always restricted in voting for the party alone but also campaigning for the party to their friends, family and co-workers. The theory also helps us to understand why the poor and the illiterate are the easiest of the client to be targeted. This is because the flow of patron client relationship is from those that have to those that have not.

\section{Research Methodology}

\section{Research Design}

Research design is to be the structure of every research. Zikmund (1988) defined research design as the master plan which contains the methods and procedure to be used in collecting and analyzing information necessary for the research. Manheim (1977) explains that research design does not only anticipate or recommend the different decisions necessary for collecting, processing and analyzing of data but also gives a logical basis for these decisions. The research design employed in this research is the descriptive survey (the single cross section) which involves observing and describing the behavior or getting a precise measurement of a subject without influencing it (Loeb et al., 2017). The single cross section requires the collection of information from a selected sample at a single point in time and used to represent or draw inference about the entire population, this can be used to form causal explanation of a particular phenomenon (Silva, 2017). In this context the design vividly shows current conditions that exist between specific events i.e. vote buying and democratic election. This design enables the research to explain, record, analyze and interpret the conditions that exists in relations to the subject matter.

The population in this research comprising of public and civil service workers; teachers, university students, staff of universities and private business owner. These of individuals can be seen below

Table 3.1: Population of Individuals from 18-Above in Ekiti State

\begin{tabular}{|c|c|c|}
\hline S/N & AGE RANGE & POPULATION (Based on the 2006 Census) \\
\hline 1 & $18-29$ years & 464,898 \\
\hline 2 & $30-39$ years & 277,497 \\
\hline 3 & $40-49$ years & 209,275 \\
\hline 4 & $50-59$ years & 126,226 \\
\hline 5 & $60-69$ years & 77,255 \\
\hline
\end{tabular}




\begin{tabular}{|c|c|c|}
\hline 6 & $70-79$ years & 35,459 \\
\hline 7 & 80 -above years & 24,701 \\
\hline & & $1,215,311$ \\
\hline
\end{tabular}

(City Population, 2017).

These set of individual's range 18-69 which largely represent the highest Percentage of voters in the state. The justification for limiting the research to 69 age is because records shows that the population of people above 69 in Ekiti state are very small as well as scarcely available to respond to questionnaires and interviews (Adetoye, and Omilusi, 2016; City Population, 2017). The population was derived from five local government areas of Ekiti state namely Oye (North) with a population of 137,796, Ado Ekiti (Center) with a population of 313,690, Ekiti West (West) with a population of 179,600, Ekiti East (East) with a population of 138,340 and Ikere (South) with a population of 148,558. The justification for picking these five local government areas is that these areas gives good representation of Ekiti State, consist of all the individuals needed for the research population as well as covering at the five cardinal points of Ekiti State. That is North Center, West, East and South.

The sample size for this research was determined using Gill et al. (2010)

Table 3.2: Sample Size Determiner

\begin{tabular}{|c|c|c|c|}
\hline \multicolumn{4}{|c|}{ Variance of the Population $\mathrm{P}=80 \%$} \\
\hline \multicolumn{4}{|c|}{ Confidence Level =95\%, Margin of Error } \\
\hline Population Size & 5 & 3 & 1 \\
\hline 50 & 45 & 48 & 50 \\
\hline 75 & 63 & 71 & 75 \\
\hline 100 & 80 & 92 & 99 \\
\hline 150 & 109 & 132 & 148 \\
\hline 200 & 132 & 169 & 196 \\
\hline 250 & 152 & 203 & 244 \\
\hline 300 & 169 & 235 & 291 \\
\hline 400 & 197 & 292 & 385 \\
\hline 500 & 218 & 341 & 476 \\
\hline 600 & 235 & 385 & 565 \\
\hline 700 & 249 & 423 & 653 \\
\hline 800 & 260 & 458 & 739 \\
\hline 1000 & 278 & 517 & 906 \\
\hline 1500 & 306 & 624 & 1298 \\
\hline 2000 & 323 & 697 & 1656 \\
\hline 3000 & 341 & 788 & 2287 \\
\hline 5000 & 357 & 880 & 3289 \\
\hline 10000 & 370 & 965 & 4900 \\
\hline 25000 & 378 & 1023 & 6939 \\
\hline 50000 & 381 & 1045 & 8057 \\
\hline 100000 & 383 & 1056 & 8762 \\
\hline 250000 & 384 & 1063 & 9249 \\
\hline 500000 & 384 & 1065 & 9423 \\
\hline 1000000 & 384 & 1066 & 9513 \\
\hline 2000000 & 385 & 1067 & 9558 \\
\hline
\end{tabular}

(Gill et al. 2010; cited in Taherdoost, 2017: 238) 
Gill et al. (2010) who explained that an population size of 1,000,000-2,000,000 with a 5\% margin of error a minimum of 385 should be used as the sample size (cited in Taherdoost, 2017). However, because of the possibility of unreturned materials with an $80 \%$ estimated response rate, the sample size calculator advocated that at least 410 respondents should be targeted (check market, 2019). Therefore the sample size for the research is 410

The sampling technique employed was the purposive sampling method. Purposive sample, also known as judgmental sample, is a nonprobability sampling method, were the researcher (Palys, 2008). Using this sampling method allows the research target individuals among the population whose responses will be critical to the subject matter.

This research makes use of both Primary and secondary source of data. The primary sources of data include structured oral interviews and questionnaires. Oral data involves the technique of one-on-one interview with persons considered relevant to the elections including INEC officials that conducted the election, NYSC corps members used as ad hoc staff, party officials that participated in the election. The questionnaires on the other hand, involved a well-structured closed ended line of questions targeted at gathering relevant data as related to the election. Secondary sources of data for this research include books, journals, newspapers, unpublished thesis and the internet.

The five point Likert Scale questionnaire was adapted as the main instrument for data collection. The instrument was considered suitable for this research because previous users have made use of the type of questionnaire and found it suitable for carrying out their research (Nemoto and Beglar, 2014). The Five Point Likert Scale questionnaire ranging from Strongly Agree to Strong Disagree allows the respondent express their views in relations to the question asked. Structured oral interviews allows the researcher to ask question relevant to the research and prevents the interviewer target issues that are pertinent to the research and not deviate off the subject matter.

The Research used content validity to ensure the validity of the instrument. A content validity ensures that the research instrument accurately measures all aspects of what it was designed to measure (Kimberlin and Winterstein, 2008). This was done by subjecting it to the research supervisor who is grounded on the subject matter and other expertise in the field. A pilot test was also carried out to ensure that the questionnaire was clear to the respondent and that they understood the question asked. Twenty copies of the questionnaires were administered in Ado Ekiti to civil servants and private business owners which were not marked for the research but part of the population. The Cronbach's alpha was further used to ascertain the internal consistency of the instrument, taking into consideration the thumb rule of Crobach's alpha which states that 0.7 and above is good, 0.8 and above is better and 0.9 and above is best although, there is no universal minimally acceptable reliability value (Bonett and Wright, 2014). The reason for adopting the internal consistency reliability of the instrument was to enable the researcher know whether the item on the instrument were consistent with one another, in that they represent one dimension or area of interest (Bonett and Wright, 2014).

Table 3:3 Case Processing Summary of Pilot Research

\begin{tabular}{|l|c|c|c|}
\hline \multicolumn{2}{|c|}{} & $\mathrm{N}$ & $\%$ \\
\hline \multirow{3}{*}{ Cases } & Valid & 20 & $100 \%$ \\
\cline { 2 - 4 } & Excludeda & 0 & .0 \\
\cline { 2 - 4 } & Total & 20 & $100 \%$ \\
\hline
\end{tabular}


This shows that Twenty (20) copies of questionnaire were administered to respondents in Ado-Ekiti and used for the pilot research.

Table 3:4 Reliability Statistics of Vote Buying and Democratic Election Questionnaire

\begin{tabular}{|c|c|c|}
\hline Cronbach's Alpha & $\begin{array}{c}\text { Cronbach's Alpha Based on } \\
\text { Standardized Items }\end{array}$ & No of Items \\
\hline .892 & .888 & 20 \\
\hline
\end{tabular}

Table 3:4 reveals that there is a high level of reliability, using the cronbach' alpha with a result of 0.89 which is above 0.7 that is assumed as the minimum required level of reliability. This indicates that the items of the instrument were consistent with one another and is reliable (Bonett and Wright, 2014).

\section{Table 3:5 Item-Total Statistics}

\begin{tabular}{|c|c|c|c|c|}
\hline Variables & $\begin{array}{l}\text { Scale } \mathrm{N} \\
\text { if } \\
\text { Deleted }\end{array}$ & $\begin{array}{l}\text { Mean Scale } \\
\text { ItemVariance i } \\
\text { Item Deleted } \\
\end{array}$ & $\begin{array}{l}\text { Corrected I } \\
\text { ifTotal } \\
\text { Correlation } \\
\end{array}$ & $\begin{array}{l}\text {-Cronbach's } \\
\text { Alpha if Item } \\
\text { Deleted }\end{array}$ \\
\hline $\begin{array}{l}\text { Party agents give money to the electorates to } \\
\text { buy their votes around the polling centres }\end{array}$ & 32.90 & 81.042 & . 133 & .894 \\
\hline $\begin{array}{l}\text { Candidates use campaign materials such as } \\
\text { food stuff, clothing materials and money as } \\
\text { instrument for vote buying }\end{array}$ & s 32.80 & 71.958 & .810 & .879 \\
\hline $\begin{array}{l}\text { Party agents gave youths groups and } \\
\text { association money to influence their voting } \\
\text { choice }\end{array}$ & 32.10 & 81.147 & . 013 & .898 \\
\hline $\begin{array}{l}\text { Party agents required evidence of voting before } \\
\text { payment were released }\end{array}$ & 31.85 & 74.871 & .502 & .887 \\
\hline $\begin{array}{l}\text { Traditional rulers were given money and food } \\
\text { stuffs to influence their subject to vote for a } \\
\text { particular party and candidate }\end{array}$ & 32.00 & 74.737 & .398 & .891 \\
\hline Vote buying results in distrust for candidates & 32.25 & 69.250 & .701 & .880 \\
\hline Some voters believe their votes did not count & 32.05 & 69.103 & 639 & .883 \\
\hline Vote buying negates the principle of fairness & 32.45 & 70.787 & .802 & .878 \\
\hline Vote buying promotes corruption & 32.30 & 71.800 & 666 & .882 \\
\hline $\begin{array}{l}\text { Some eligible candidates refused to participate } \\
\text { in the election due to vote buying }\end{array}$ & 31.80 & 72.905 & .533 & .886 \\
\hline $\begin{array}{l}\text { High rate of poverty amongst the electorate } \\
\text { encouraged vote buying }\end{array}$ & 32.85 & 79.397 & .390 & .891 \\
\hline $\begin{array}{l}\text { Lack of voters' education encouraged vote } \\
\text { buying }\end{array}$ & 32.80 & 71.958 & 810 & .879 \\
\hline Security agents turned blind eye to vote buying & 32.35 & 74.450 & .572 & .885 \\
\hline $\begin{array}{l}\text { The believe that candidates that buy votes are } \\
\text { generous encouraged vote buying }\end{array}$ & 31.80 & 73.747 & .473 & .888 \\
\hline $\begin{array}{l}\text { Lack of trust in the promises of candidates } \\
\text { encouraged vote buying }\end{array}$ & 31.75 & 69.145 & 647 & .882 \\
\hline $\begin{array}{l}\text { Vote buying should be added to the criminal } \\
\text { code and long term sentence given to offenders }\end{array}$ & 32.15 & 73.187 & 499 & .887 \\
\hline $\begin{array}{l}\text { Voter education should be conducted before } \\
\text { future elections }\end{array}$ & 32.40 & 72.568 & .474 & .889 \\
\hline $\begin{array}{l}\text { Ekiti State Government should embark on } \\
\text { grass root poverty alleviation scheme to }\end{array}$ & 31.95 & 73.629 & .540 & .886 \\
\hline
\end{tabular}




\begin{tabular}{|c|c|c|c|}
\hline $\begin{array}{l}\text { prevent candidates from taking advantage of } \\
\text { the poor electorates }\end{array}$ & & & \\
\hline $\begin{array}{l}\text { EFCC and ICPC should investigate party } \\
\text { finances to curb vote buying }\end{array}$ & 79.418 & .132 & .897 \\
\hline $\begin{array}{l}\text { Candidates should be disqualified if found } 32.45 \\
\text { guilty of vote buying }\end{array}$ & 76.682 & .431 & .889 \\
\hline
\end{tabular}

The table above shows that all the variables indicated on the scale mean if item is deleted is above 31 which is statistical higher then valid level of 25 . The total correlation of all the items is positive and the Cronbach's Alpha if any item is deleted is over 0.87 . This means that the items in the research have over $87 \%$ level of reliability.

\section{Method of Data Analysis}

The research techniques use to analyze data is T-test (one single sample test). Ttest is probability distribution similar to the Normal distribution. It is commonly used to test hypotheses involving numerical data. It is often used when the research intends to summarise the group with one statistic and when the underlying population data is normally distributed. In which the best summary statistic is the mean (Ugoni, and Walker, 1995). The justification for using this method of data analysis is that it aids the researcher to effectively compare statistical data derived from vote buying and that of the expectation of democratic election. The research adhered to a number of ethical consideration principles while the research was carried out for both the questionnaire administration and interview schedules. On meeting with the prospective participate (respondents) the researcher was formally introduced and then went ahead to explain what the research entailed and what role they were expected to play. Furthermore, the different respondents were informed that the information provided will be utilized strictly for research purposes and their information will be kept confidential. A contact number was provided on the cover letter attached to the questionnaire that was distributed to the respondent in their office, school and business location. The researcher allowed the respondent to fill the questionnaire at their convenience and return to the researcher at a later date. The researcher also returned to the respondent at a later date to collect the questionnaires distributed, that was not collected on the day it was shared. The interview sessions also took ethical considerations, the respondent were first informed that they were been recorded and only those who agreed, got recorded. The individuals who responded to the questionnaires and interviews were kept anonymous when the report of the research was been analysed and the findings presented as agreed by the research and the respondent.

\section{Brief History of Ekiti State and its Political Leaders}

Present day Ekiti State located in South West Nigeria, was created on October 1, 1996 by the administration of late General Sani Abacha. Ekiti State was formed out of old Ondo state as a result of the struggle by the people of present day Ekiti State for selfdetermination and development (Fasuan, 2002). The neighboring state surrounding Ekiti state includes Ondo State to the south, Kwara State to the North and Kogi State to the east. Agriculture is the most prominent occupation of the people of Ekiti which provides income and employment for more than $75 \%$ of the population. The Ekiti state population is estimated at 2,737,186 with a total land mass of 6,353 km2 (2,453 sq mi). The Ekiti state endowed with both human and mineral resources which are yet to be effectively utilized 
for the good of the country (Jadesola, 2017). The agitators for the creation of Ekiti state alongside the council in charge of the state creation project submitted a report to show the viability of the state and as such did not need the regular take-off grant given to most newly created state, which convinced the Abacha Administration that Ekiti state was a viable state which had no need for financial support from the central government. However, the expectation of the agitators were not a reality as no sooner after the state got created, Ekiti State became solely overdependence on allocation from federation account because of low internally generated revenue. The allocation gotten from the federal account has become the major source of income that caters for monthly the payment of salaries, wages and other bureaucratic and political expenses of the government (Fasuan, 2002; Adetoye, 2010). When Ekiti State got created in 1996; Lt. Col. Mohammed Bawa was made the military administrator from October 1996 to August 1998 and then Navy Captain Atanda Yusuf from August 1998 to May 1999. At the transition to Democracy in 1999, Niyi Adebayo became governor of Ekiti State a grassroots candidate of the Alliance for Democracy (AD). In 2003 Mr. Ayo Fayose of the People's Democratic Party (PDP) was elected as Governor of Ekiti state, This was part of the agenda of the PDP to sweep the whole of South west which was almost a success. Ayo Fayose was impeached by the State House of Assembly three years into tenure and his administration terminated. After the impeachment of Fayose's on October 16 by the State Assembly was briefly replaced by an Acting governor Friday Aderemi who was later declared illegal by Federal Government on October 18, 2006. The political tension built up to political crisis which made President Olusegun Obasanjo declare a state of emergency on Ekiti state and appointed General Tunji Olurin to be the administrator from 18th October, 2006- 27 April, 2007. Tope Ademiluyi replaced Tunji Olurin as Acting Governor from 27 April, 2007-29th May, 2007 (Jadesola, 2012). Segun Oni became Governor from 29th May, 2007-15th October, 2010 after the election of Oni was terminated by the court and Dr. Kayode Fayemi was declared the duly elected governor of Ekiti State. The 2014 election was an election which was furiously fought for by the PDP and the AD for the PDP it was the opportunity to win back Ekiti which it lost to $\mathrm{AD}$ and for the $\mathrm{AD}$ it was a fight to retain power however, for both Parties it will be an opportunity to break one term jinx by both parties. The 2014 election was however, won by Fayose of PDP (Adetoye, and Omilusi, 2016).

\section{The 2018 Governorship election in ekiti state}

Ayo Fayose of the PDP tenure as governor of Ekiti state was to end on 15th October, 2018 and according to the provision of section 178(1) and (2) of the 1999 constitution of the federal republic of Nigeria as amended and section 25(7) and (8) of the 2010 Electoral Act as amended. The earliest time for the election to hold was 19th May, 2018 and the latest was 15th September, 2018 (Adeseun, 2017). The Electoral Act also state that the commission which is INEC is expected to give notice about the election not later than 90 days before the election. The INEC calendar for the Governorship election in ekiti state is as follows

Notification of the Election

Commencement of Campaign Activities

4th April, 2018

Collection of Forms by Political Parties

15th April, 2018

Conducting Party Primaries

16th April, 2018

Last day for submission of forms

15th April-14th May, 2018

15th May, 2018 
Date of the Election

14th July, 2018 (Adeseun, 2017).

Following the announcement and presentation of INEC electoral calendar, registered political parties qualified to contest for the Gubernatorial Election of Ekiti State were to conduct their primaries from the 15th April-14th of May, 2018. As part of the requirement of INEC political parties were required to inform INEC regarding information about their primaries such as time, date and venue for the conduct of the primaries and so on within 21 days. To ensure that the primaries meets up to the tenants of democracy, political parties were obligated to conduct their party primaries with through direct nominee selection by members of the political party or by indirect-nominee selected by delegates. In a report provided by YIAGA Africa which focused on some political parties primaries namely: Action Democratic Party (ADP), Mega Party (MP), All Progressives Congress (APC), Social Democratic Party (SDP) and The People's Democratic Party (PDP). It was observed that three of the parties focused on which were APC, PDP and Mega Party adopted the indirect primary system while AD and SDP adopted the direct nominee selection (YIAGA Africa, 2018). Most of the party primaries adopted an open secret ballot voting system; however the set-up of the voting booth had the tendency to undermine the secrecy of the ballot system. The party primaries were relatively peaceful expect the APC primaries which had an outbreak of violence which require a need for a new primaries (C.D.D, 2018).

The INEC timetable stipulated that the official campaign for the 2018 Governorship election in ekiti state was to begin on the 15th of April 2018, several political parties organized rallies and other campaign activities across the different Local Government Areas in Ekiti state. It was observed that the campaign rallies and activities was mostly from four political parties the (ADP) Action Democratic Party, (APC) All Progressives Congress, the (PDP) People's Democratic Party and the (SDP) Social Democratic Party .

In a report provided by YIAGA Africa it was observed that across the state $42 \%$ of individuals witnessed or heard a rally conducted by ADP in different Local Government Areas, 59\% reported witnessing or hearing of APC rallies in different local government areas and $75 \%$ reported witnessing or hearing of rallies for the PDP in different Local Government Areas and only 17\% reported hearing but not witnessing of rallies by the Social Democratic Party (SDP) (YIAGA Africa, 2018).

The election campaign was also joined with different evidence of vote buying These evidence included reports of buying and selling of voters' cards, distribution of money or gift items by candidates or their supports. In a report provided by YIAGA Africa it was observed that across the state $4 \%$ of individuals heard plausible reports of voters' cards being sold or bought and more than 54\% either observed or witness distribution of money or gift items induced by politicians or their supporters in different locations (C.D\&D, 2018; YIAGA Africa, 2018). On the 15th of July the Election Day, polling centers opened relatively on time with accreditations going smoothly in most polling centers at 10am except in Eleke which could start accreditation of voters as a result of faulty card readers which only got fixed at past 11am (Sahara reporters, 2018). The security agents and local observers were represented in almost all the polling center in the state. It was also observed that party supporters and agents were also very active and conversing for votes around the polling centers which was against the electoral laws which states that campaigning was to end 24 hours before the commencement of the election, most security agents initially gave the impression of trying to prevent party agents and supports from conversing or 
influencing voter's choice but as soon as accreditation concluded and polling centers commenced allowing electorates to cast their votes for the different parties the security agents literally turned a blind eye towards individuals influencing voters before they got to cast their votes. Some media personals and observers identified different party agents and supporters discussing with different INEC officials, NYSC personal and buying drinks for the security agents. The 2018 Ekiti State Election was mostly peaceful with little or no major incidents of Electoral violence during the election except in Udi Ado Ekiti were a party agent was poured acid by an unidentified individual and some report of ballot box snatching at Ileje-Meje and Ward 3 Unit 4 in Ikole Ekiti (Sahara reporters, 2018). As the election was concluded and the counting began it was evident that the Ekiti governorship election was a straight contest between Olusola Eleka of the PDP and Kayode Fayemi of the APC below are the result based on different local government between PDP and APC Based on the above result from the Governorship election in ekiti state conducted on Saturday 15th July 2018. The All Progressive Congress (APC) candidate Dr. Kayode Fayemi was declared the winner defeating his closest rival and candidate of the People's Democratic Party (PDP), Prof Kolapo Olusola with 19,338 votes. Fayemi got 197,459 and Olusola, got 178,121 votes (Nseyen, 2018).

\section{Data Presentation, Analysis and Interpretation}

This chapter presents the data obtained from the field, 410 copies of questionnaire were administered. However, only 404 were retrieved. 389 were correctly filled, 15 were erroneously filled and 7 were not returned. The data were analyzed with the aid of a Number distribution table with the opinions of respondents arranged in Percentage and hypotheses were tested.

Distribution of Bio Data of Respondents

Table 4.1: Sex of Respondents

\begin{tabular}{|c|c|c|}
\hline & Number & Percentage \\
\hline Male & 202 & 51.9 \\
\hline Female & 187 & 48.1 \\
\hline Total & 389 & $100 \%$ \\
\hline
\end{tabular}

The table indicates that $51.9 \%$ of the research respondents are men while $48.1 \%$ are women. This means that the largest percentages of the research respondents are men. This is because based on the 2006 general election the population of men is greater than the population of women in Ekiti State (City Population, 2017).

Table 4.2: Age of Respondents

\begin{tabular}{|c|c|c|}
\hline & Number & Percentage \\
\hline $18-29$ & 218 & 56.0 \\
\hline $30-39$ & 74 & 19.0 \\
\hline $40-49$ & 45 & 11.6 \\
\hline $50-59$ & 35 & 9.0 \\
\hline $60-69$ & 17 & 4.4 \\
\hline Total & 389 & $100 \%$ \\
\hline
\end{tabular}


The table above reveals that $56 \%$ of the research respondents are within the age range of $18-29 ; 19 \%$ are from $30-39,11.6 \%$ are within the age of $40-49,9 \%$ of the research respondents are within the age range of 50-59 while $4.4 \%$ are within the age range of 60 69 . This means that largest percentages of the research respondents which constitute $56 \%$ are within the age range of 18-29. This is because based on the 2006 census Ekiti State age range between 18-29 is the third highest age range in Ekiti state population with 464,898 and the highest voting age range.

Table 4.3: Marital Status of Respondents

\begin{tabular}{|c|c|c|}
\hline & Number & Percentage \\
\hline Single & 239 & 61.4 \\
\hline Married & 150 & 38.6 \\
\hline Total & 389 & $100 \%$ \\
\hline
\end{tabular}

In table 4.3 , it is evident that $61.4 \%$ of the research respondents are singles while $38.6 \%$ are married. This shows that there are more singles compared to the married people in the research. This because there are more single individuals than married individuals in Ekiti State

Table 4.4: Educational Qualification

\begin{tabular}{|c|c|c|}
\hline & Number & Percentage \\
\hline SSCE & 107 & 27.5 \\
\hline OND & 25 & 6.4 \\
\hline HND & 45 & 11.6 \\
\hline BSc & 146 & 37.5 \\
\hline MSc & 45 & 11.6 \\
\hline PhD & 21 & 5.4 \\
\hline Total & 389 & $100 \%$ \\
\hline
\end{tabular}

This shows that $27.5 \%$ of the research respondents are holders of Senior School Certificate Examination (SSCE) $6.4 \%$ of the research respondents have Ordinary National Diploma (OND), 11.6\% are Higher National Diploma (HND) holders, 37.5\% have Bachelor of Science degree (BSc), 11.6\% have Masters of Science degree while 5.4\% have Doctor of Philosophy $(\mathrm{PhD})$. With the results illustrated in this table it indicates that the level of education in Ekiti state is very high and thus it can be tagged an educationally advantage state with majority of the research respondents which constitute $37.5 \%$ having a first degree (Bachelor of Science degree). This however, aided the research because most of the population could read and write

Table 4.5: State of Origin

\begin{tabular}{|c|c|c|}
\hline & Number & Percentage \\
\hline Ekiti State & 222 & 57.1 \\
\hline Non-Indigene of Ekiti State & 167 & 42.9 \\
\hline Total & 389 & $100 \%$ \\
\hline
\end{tabular}

The table above reveals that $57.1 \%$ of the research respondents are indigenes of Ekiti state, while $42.9 \%$ are non-Indigene of Ekiti State. There are more indigenes of Ekiti in the research because Ekiti state served as the research area. 


\section{Presentation and Interpretation of Questionnaire}

Table 4.6: Party agents give money to the electorates to buy their votes around the polling centres.

\begin{tabular}{|l|l|l|}
\hline & Number & Percentage \\
\hline Strongly Agree & 276 & 71.0 \\
\hline Agree & 49 & 12.6 \\
\hline Undecided & 26 & 6.7 \\
\hline Disagree & 24 & 6.2 \\
\hline Strongly Disagree & 14 & 3.6 \\
\hline Total & 389 & $100 \%$ \\
\hline
\end{tabular}

The table above shows that $71 \%$ of the research respondents ticked strongly agreed that party agents give money to the electorates to buy their votes around the polling centres, $12.6 \%$ ticked agreed, 6.7\% ticked undecided, 6.2\% ticked disagreed while $3.6 \%$ of the research respondents ticked strongly disagreed. Based on this, it means that party agents actually give money to the electorates to buy their votes around the polling centres in order to enhance the winning chance of their candidates.

Table 4.7: Candidates use campaign materials such as food stuff, clothing materials and money as instrument for vote buying

\begin{tabular}{|c|c|c|}
\hline & Number & Percentage \\
\hline Strongly Agree & 263 & 67.6 \\
\hline Agree & 77 & 19.8 \\
\hline Undecided & 17 & 4.4 \\
\hline Disagree & 18 & 4.6 \\
\hline Strongly Disagree & 14 & 3.6 \\
\hline Total & 389 & $100 \%$ \\
\hline
\end{tabular}

The table above shows that $67.6 \%$ of the research respondents ticked strongly agreed, that candidates use campaign materials such as food stuff, clothing materials and money as instrument for vote buying, $19.8 \%$ of the research respondents ticked agreed, $4.4 \%$ ticked undecided while $4.6 \%$ ticked disagreed and 3.6\% strongly ticked disagreed.

This means that political party candidates used materials to induce voters and solicit for their votes at polling units, in order to increase their winning chance in the governorship election in Ekiti State; this was wide spread across the polling units, wards and local governments of the state.

Table 4.8: Party agents gave youth groups and association money to influence their voting choice

\begin{tabular}{|c|c|c|}
\hline & Number & Percentage \\
\hline Strongly Agree & 152 & 39.1 \\
\hline Agree & 161 & 41.4 \\
\hline Undecided & 50 & 12.9 \\
\hline Disagree & 18 & 4.6 \\
\hline Strongly Disagree & 8 & 2.1 \\
\hline Total & 389 & $100 \%$ \\
\hline
\end{tabular}

The table above reveals that $39.1 \%$ of the research respondents ticked strongly agreed that Party agents gave youth groups and association money to influence their voting choice, 
41.4\% ticked agreed, $12.9 \%$ ticked undecided, $4.6 \%$ of the research respondents ticked disagreed, while $2.1 \%$ strongly ticked disagreed.

Table 4.9: Party agents required evidence of voting before payment were released

\begin{tabular}{|c|c|c|}
\hline & Number & Percentage \\
\hline Strongly Agree & 116 & 29.8 \\
\hline Agree & 137 & 35.2 \\
\hline Undecided & 91 & 23.4 \\
\hline Disagree & 31 & 8.0 \\
\hline Strongly Disagree & 14 & 3.6 \\
\hline Total & 389 & $100 \%$ \\
\hline
\end{tabular}

The table above shows that $29.8 \%$ of the research respondents ticked strongly agreed that party agents required evidence of voting before payment were released, 35.2\% ticked agreed, 23.4\% ticked undecided, $8 \%$ ticked disagreed while $3.6 \%$ of the research respondents ticked strongly disagreed. This means that party agents demand proof from the electorates to confirm they voted for their party before giving them money in return.

Table 4.10: Traditional rulers were given money and food stuffs to influence their subject to vote for a particular party and candidate

\begin{tabular}{|c|c|c|}
\hline & Number & Percentage \\
\hline Strongly Agree & 112 & 28.8 \\
\hline Agree & 140 & 36.0 \\
\hline Undecided & 83 & 21.3 \\
\hline Disagree & 37 & 9.5 \\
\hline Strongly Disagree & 17 & 4.4 \\
\hline Total & 389 & $100 \%$ \\
\hline
\end{tabular}

The table above indicates that $28.8 \%$ of the research respondents ticked strongly agreed to the fact that traditional rulers were given money and food stuffs to influence their subject to vote for a particular party and candidate, 36\% of the research respondents ticked agreed, $21.3 \%$ ticked undecided, 9.5\% ticked disagreed, while $4.4 \%$ of the research respondents ticked strongly disagreed. This means that royal fathers in Ekiti state were actually given money and food stuffs to influence their subject to vote for a particular party and candidate based on the data from the field.

Table 4.11: Vote buying results in distrust for candidates

\begin{tabular}{|c|c|c|}
\hline & Number & Percentage \\
\hline Strongly Agree & 203 & 52.2 \\
\hline Agree & 97 & 24.9 \\
\hline Undecided & 54 & 13.9 \\
\hline Disagree & 21 & 5.4 \\
\hline Strongly Disagree & 14 & 3.6 \\
\hline Total & 389 & $100 \%$ \\
\hline
\end{tabular}

The table above shows that $52.2 \%$ of the research respondents ticked strongly agreed that vote buying results in distrust for candidates, 24.9\% ticked agreed, $13.9 \%$ ticked undecided, $5.4 \%$ of the research respondents disagreed and $3.6 \%$ of the research 
respondents ticked strongly disagreed. This indicates that act of vote buying actually led to electorates distrust for candidates.

Table 4.12: Some voters believe their votes did not count

\begin{tabular}{|c|c|c|}
\hline & Number & Percentage \\
\hline Strongly Agree & 190 & 48.8 \\
\hline Agree & 132 & 33.9 \\
\hline Undecided & 28 & 7.2 \\
\hline Disagree & 24 & 6.2 \\
\hline Strongly Disagree & 15 & 3.9 \\
\hline Total & 389 & $100 \%$ \\
\hline
\end{tabular}

The table shows that $48.8 \%$ of the research respondents ticked strongly agreed that their votes did not count, 33.9\% ticked agreed, 7.2\% ticked undecided, 6.2\% ticked disagreed, while $3.9 \%$ strongly disagreed. This implies that the respondents were of the view that there votes did not count as they were manipulated by the party agents and candidates especially with the act of voting buying and voters inducement. The rich party agents bought way to victory and power while others couldn't coast to victory based on fairness.

Table 4.13: Vote buying negates the principle of fairness

\begin{tabular}{|c|c|c|}
\hline & Number & Percentage \\
\hline Strongly Agree & 216 & 55.5 \\
\hline Agree & 122 & 31.4 \\
\hline Undecided & 16 & 4.1 \\
\hline Disagree & 21 & 5.4 \\
\hline Strongly Disagree & 14 & 3.6 \\
\hline Total & 389 & $100 \%$ \\
\hline
\end{tabular}

The table above indicates that $55.5 \%$ of the research respondents ticked strongly agreed that vote buying negates the principle of fairness, $31.4 \%$ ticked agreed, $4.1 \%$ ticked undecided, 5.4\% ticked disagreed, while 3.6\% ticked strongly disagreed. This implies that vote buying actually negated the principle of fairness at the 2018 Ekiti State governorship elections.

Table 4.14: Vote buying promotes corruption

\begin{tabular}{|c|c|c|}
\hline & Number & Percentage \\
\hline Strongly Agree & 202 & 51.9 \\
\hline Agree & 127 & 32.6 \\
\hline Undecided & 34 & 8.7 \\
\hline Disagree & 15 & 3.9 \\
\hline Strongly Disagree & 11 & 2.8 \\
\hline Total & 389 & $100 \%$ \\
\hline
\end{tabular}

The table above reveals that $51.9 \%$ of the research respondents ticked strongly agreed that vote buying promotes corruption, 32.6\% ticked agreed, $8.7 \%$ ticked undecided, 3.9\% ticked disagreed while $2.8 \%$ ticked strongly disagreed. Based on this, vote buying is seen as the factor that promotes corruption in this research.

Table 4.15: Some eligible candidates refused to participate in the election due to vote buying 


\begin{tabular}{|c|c|c|}
\hline Strongly Agree & 136 & 35.0 \\
\hline Agree & 133 & 34.2 \\
\hline Undecided & 67 & 17.2 \\
\hline Disagree & 36 & 9.3 \\
\hline Strongly Disagree & 17 & 4.4 \\
\hline Total & 389 & $100 \%$ \\
\hline
\end{tabular}

This table reveals that 35\% of the research respondents ticked strongly agreed that some eligible candidates refused to participate in the election due to vote buying, $34.2 \%$ ticked agreed, $17.2 \%$ ticked undecided, $9.3 \%$ ticked disagreed while $4.4 \%$ of the research respondents ticked disagreed. This implies that certain persons felt that there was no need of participating in the voting process because the true choice of the people will not prevail. Rather it's the rich that wins all due to his economy power to induce voters.

Table 4.16: High rate of poverty amongst the electorate encouraged vote buying

\begin{tabular}{|c|c|c|}
\hline & Number & Percentage \\
\hline Strongly Agree & 260 & 66.8 \\
\hline Agree & 81 & 20.8 \\
\hline Undecided & 25 & 6.4 \\
\hline Disagree & 15 & 3.9 \\
\hline Strongly Disagree & 8 & 2.1 \\
\hline Total & 389 & $100 \%$ \\
\hline
\end{tabular}

It is evident in table 4.16 , that $66.8 \%$ strongly agreed to high rate of poverty amongst the electorate as the factor that encouraged vote buying in 2018 Ekiti State governorship election, 20.8\% ticked agreed, 6.4\% ticked undecided, 3.9\% ticked disagreed, while 2.1\% strongly disagreed. This means that poverty actually made the electorates vulnerable to vote buying in order to survive.

Table 4.17: Lack of voters' education encouraged vote buying

\begin{tabular}{|c|c|c|}
\hline & Number & Percentage \\
\hline Strongly Agree & 233 & 59.9 \\
\hline Agree & 98 & 25.2 \\
\hline Undecided & 26 & 6.7 \\
\hline Disagree & 21 & 5.4 \\
\hline Strongly Disagree & 11 & 2.8 \\
\hline Total & 389 & $100 \%$ \\
\hline
\end{tabular}

The table above reveals that $59.9 \%$ of the research respondents ticked strongly agreed that lack of voters' education encouraged vote buying at the 2018 Ekiti State governorship, 25.2\% ticked agreed, 6.7\% ticked undecided, 5.4\% ticked disagreed while $2.8 \%$ strongly disagreed. This means that lack of voters' education actually encouraged vote buying, because the voters were not properly sensitized by political parties and electoral officers prior to the election. The choice candidates by voters as a result of the foregoing were greatly influenced by vote buying.

Table 4.18: Security agents turned blind eye to vote buying

\begin{tabular}{|c|c|c|}
\hline & Number & Percentage \\
\hline Strongly Agree & 197 & 50.6 \\
\hline
\end{tabular}




\begin{tabular}{|c|c|c|}
\hline Agree & 116 & 29.8 \\
\hline Undecided & 53 & 13.6 \\
\hline Disagree & 12 & 3.1 \\
\hline Strongly Disagree & 11 & 2.8 \\
\hline Total & 389 & $100 \%$ \\
\hline
\end{tabular}

The table shows that $50.6 \%$ of the research respondents ticked strongly agreed that security agents turned blind eye to vote buying, 29.8\% ticked agreed, $13.6 \%$ ticked undecided while 3.1\% ticked disagreed, $2.8 \%$ strongly disagreed. This means that the security agents did not play any major role towards curbing vote buying in the 2018 Ekiti State governorship election.

Table 4.19: The believe that candidates that buy votes are generous encouraged vote buying

\begin{tabular}{|c|c|c|}
\hline & Number & Percentage \\
\hline Strongly Agree & 160 & 41.1 \\
\hline Agree & 125 & 32.1 \\
\hline Undecided & 44 & 11.3 \\
\hline Disagree & 36 & 9.3 \\
\hline Strongly Disagree & 24 & 6.2 \\
\hline Total & 389 & $100 \%$ \\
\hline
\end{tabular}

The table reveals that $41.1 \%$ of the research respondents ticked strongly agreed that candidates that buy votes are generous encouraged vote buying, 32.1\% ticked agreed, $11.3 \%$ ticked undecided, 9.3\% ticked disagreed while 6.2\% strongly disagreed. This means that electorates were attracted to the cash flow from vote buying and went for the highest bidder because of generosity.

Table 4.20: Lack of trust in the promises of candidates encouraged vote buying

\begin{tabular}{|c|c|c|}
\hline & Number & Percentage \\
\hline Strongly Agree & 183 & 47.0 \\
\hline Agree & 115 & 29.6 \\
\hline Undecided & 52 & 13.4 \\
\hline Disagree & 25 & 6.4 \\
\hline Strongly Disagree & 14 & 3.6 \\
\hline Total & 389 & $100 \%$ \\
\hline
\end{tabular}

The table shows that $47 \%$ of the research respondents ticked strongly agreed that lack of trust in the promises of candidates encouraged vote buying, 29.6\% ticked agreed, $13.4 \%$ ticked undecided, 6.4\% ticked disagreed, while 3.6\% strongly disagreed. This implies that the electorates used the election as an opportunity to get their own share of the national cake since the politicians always fail in their promises after elections.

Table 4.21: Vote buying should be added to the criminal code and long term sentence given to offenders

\begin{tabular}{|c|c|c|}
\hline & Number & Percentage \\
\hline Strongly Agree & 201 & 51.7 \\
\hline Agree & 97 & 24.9 \\
\hline Undecided & 62 & 15.9 \\
\hline Disagree & 18 & 4.6 \\
\hline Strongly Disagree & 11 & 2.8 \\
\hline Total & 389 & $100 \%$ \\
\hline
\end{tabular}


This table shows that $51.7 \%$ of the research respondents ticked strongly agreed that vote buying should be added to the criminal code and long term sentence given to offenders $24.9 \%$ ticked agreed, $15.9 \%$ ticked undecided, $4.6 \%$ ticked disagreed, while $2.8 \%$ strongly disagreed. Based on the data from the field majority of respondents believe that sanctions to be given to offenders of vote buying and the act should be added to the criminal code of Nigeria.

Table 4.22: Voter education should be conducted before future elections

\begin{tabular}{|c|c|c|}
\hline & Number & Percentage \\
\hline Strongly Agree & 263 & 67.6 \\
\hline Agree & 81 & 20.8 \\
\hline Undecided & 16 & 4.1 \\
\hline Disagree & 21 & 5.4 \\
\hline Strongly Disagree & 8 & 2.1 \\
\hline Total & 389 & $100 \%$ \\
\hline
\end{tabular}

The table reveals that $67.6 \%$ of the research respondents ticked strongly agreed that voter education should be conducted before future elections, $20.8 \%$ of the research respondents agreed, 4.1\% ticked undecided, 5.4\% disagree, while 2.1\% strongly disagreed. This will acquaint the voters with the required knowledge about political parties, their symbol and their candidates, so they can make their choice and fall prey to vote buying on election day.

Table 23: Ekiti State Government should embark on grass root poverty alleviation scheme to prevent candidates from taking advantage of the poor electorates

\begin{tabular}{|c|c|c|}
\hline & Number & Percentage \\
\hline Strongly Agree & 183 & 47.0 \\
\hline Agree & 142 & 36.5 \\
\hline Undecided & 34 & 8.7 \\
\hline Disagree & 18 & 4.6 \\
\hline Strongly Disagree & 12 & 3.1 \\
\hline Total & 389 & $100 \%$ \\
\hline
\end{tabular}

The table reveals that $47 \%$ of the research respondents ticked agree that Ekiti State Government should embark on grass root poverty alleviation scheme to prevent candidates from taking advantage of the poor electorates, 36.5\% ticked agreed, 8.7\% ticked undecided, 4.6\% ticked disagreed while 3.1\% strongly disagreed. Based on this, it is clear that grass root sensitization is necessary to prevent electorates from being misled by party agents and candidates.

Table 4.24: EFCC and ICPC should investigate party finances to curb vote buying

\begin{tabular}{|c|c|c|}
\hline & Number & Percentage \\
\hline Strongly Agree & 195 & 50.1 \\
\hline Agree & 116 & 29.8 \\
\hline Undecided & 55 & 14.1 \\
\hline Disagree & 15 & 3.9 \\
\hline Strongly Disagree & 8 & 2.1 \\
\hline Total & 389 & $100 \%$ \\
\hline
\end{tabular}


The table shows that 50.1\% strongly agreed that the EFCC and ICPC should investigate party finances to curb vote buying. 29.8\% ticked agreed, 14.1\% ticked undecided, 3.9\% ticked disagreed, while $2.1 \%$ strongly disagreed.

Table 4.25: Candidates should be disqualified if found guilty of vote buying

\begin{tabular}{|c|c|c|}
\hline & Number & Percentage \\
\hline Strongly Agree & 240 & 61.7 \\
\hline Agree & 91 & 23.4 \\
\hline Undecided & 28 & 7.2 \\
\hline Disagree & 18 & 4.6 \\
\hline Strongly Disagree & 12 & 3.1 \\
\hline Total & 389 & $100 \%$ \\
\hline
\end{tabular}

In table 4.25 , it is clear that $61.7 \%$ of the research respondents ticked strongly agreed , that candidates should be disqualified if found guilty of vote buying, 23.4\% ticked agreed, 7.2\% ticked undecided, 4.6\% ticked disagreed, while 3.1\% strongly disagreed. This specifies there will be sanity in the polity when candidates who are culpable of vote are disqualified.

\section{Test of Hypotheses}

Hypothesis 1: There were no manifestations of vote buying in the 2018 Governorship election in ekiti state

Table 4.26

One-Sample Test

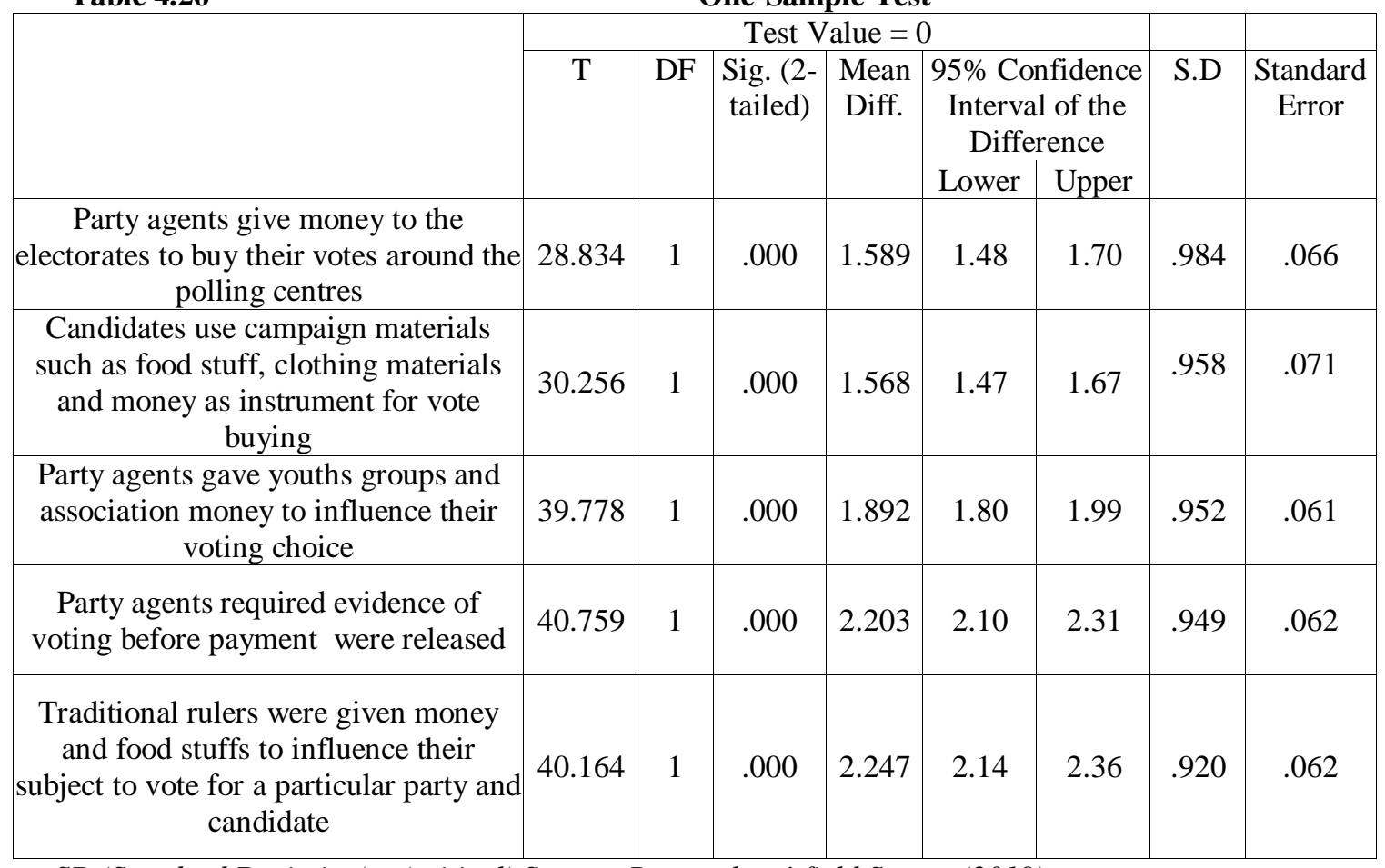

SD (Standard Deviation), t (critical) Source: Researchers’ field Survey (2019)

The hypothesis was tested using a T test, the table above shows that the t value for all the items which are 28.834, 30.256,39, 778,40.759 and 40.164 are all positive, the degree of freedom for all the items (DF) are 1 , the $\mathrm{P}$ value for all the item is 0.00 which is less than 
$(<) 0.05$ and is statistically significant. The Mean differences for all the items are 1.589, 1.568, 1.892, 2.203 and 2.247, all the standard deviation are .984, .958, .952, .949 and .920 which are all less than 1 meaning that there is a concentration of view in agreement to questions asked while the standard error is .066, .071, .061, .062, .062. This indicates that the $P$ value 0.00 which is statistically significant and the $t$ is positive. This reveals that there was actual manifestation of vote buying in the 2018 Governorship election in Ekiti State therefore, the hypothesis is rejected. This conclusion is in alignment with the claims of all individuals interviewed for the research concerning the presence and manifestation of vote buying in the 2018 governorship election in Ekiti State. All the interviewed respondent also agreed that vote buying was manifested around the vicinity of the polling center, during party rallies and that party agents required evidence of voting before payment were released. However, the male NYSC adhoc staff alone identified the use of youths and the tradition leaders towards influencing other to vote for a political party or candidate because of money as a manifestation of vote buying according to the questionnaire as well as electorates desire to determine who to vote for based on the highest bidders as other manifestation of vote buying not mentioned in the questionnaire

Hypothesis 2: Vote buying had no impact on the 2018 Governorship election in Ekiti state Table 4.27 One-Sample Test

\begin{tabular}{|c|c|c|c|c|c|c|c|c|}
\hline & \multicolumn{6}{|c|}{ Test Value $=0$} & \multirow{3}{*}{ S.D } & \multirow{3}{*}{$\begin{array}{l}\text { Standard } \\
\text { Error }\end{array}$} \\
\hline & \multirow[t]{2}{*}{$\mathrm{T}$} & \multirow[t]{2}{*}{$\mathrm{df}$} & \multirow[t]{2}{*}{$\begin{array}{l}\text { Sig. }(2- \\
\text { tailed) }\end{array}$} & \multirow[t]{2}{*}{$\begin{array}{c}\text { Mean } \\
\text { Difference }\end{array}$} & \multicolumn{2}{|c|}{$\begin{array}{l}\text { 95\% Confidence } \\
\text { Interval of the } \\
\text { Difference }\end{array}$} & & \\
\hline & & & & & Lower & Upper & & \\
\hline $\begin{array}{l}\text { Vote buying results in distrust for } \\
\text { candidates }\end{array}$ & 33.341 & 1 & .000 & 1.833 & 1.72 & 1.94 & .984 & .055 \\
\hline \begin{tabular}{|c|} 
Some voters believe their votes did not \\
count
\end{tabular} & 33.882 & 1 & .000 & 1.823 & 1.72 & 1.93 & .961 & .054 \\
\hline $\begin{array}{l}\text { Vote buying negates the principle of } \\
\text { fairness }\end{array}$ & 32.755 & 1 & .000 & 1.702 & 1.60 & 1.80 & .925 & .052 \\
\hline Vote buying promotes corruption & 35.101 & 1 & .000 & 1.730 & 1.63 & 1.83 & .972 & .049 \\
\hline $\begin{array}{c}\text { Some eligible candidates refused to } \\
\text { participate in the election due to vote } \\
\text { buying }\end{array}$ & 37.442 & 1 & .000 & 2.139 & 2.03 & 2.25 & .927 & .057 \\
\hline
\end{tabular}

SD (Standard Deviation), t (critical) Source: Researchers' field Survey (2019)

The table shows that $t$ value for all the items are 33.341, 33.882, 32.755, 35.101 and 37.442 which is positive, the degree of freedom for all the items are 1 , the $\mathrm{P}$ value for all the items are 0.00 which is less than $(<) 0.05$ and is statistically significant. The Mean difference for all the items are 1.833, 1.823, 1.702, 1.730 and 2.139 which is statistically significant, the standard deviation is .984, .961, .925, .972 and .927 which are all less than 1 meaning that there is a concentration of view in agreement to questions asked while the standard error for all the items are $0.55, .054, .052, .049$ and .057 . This indicates that $\mathrm{P}$ value of 0.00 which is statistically significant and the $t$ is positive. This reveals that vote buying had impact on the 2018 Governorship election in Ekiti state, therefore the hypothesis is rejected. This conclusion is in alignment with the claims of all individuals interviewed for the research concerning the impact of vote buying on the 2018 governorship election in Ekiti State. All the interviewed respondent ticked agreed that vote buying made individuals 
believe their votes does not count hence, a fall in turn out, vote buying promotes corruption and vote buying negates the principle of fairness which is in accordance to the question asked on the questionnaire. However, The Male INEC staff and Prof. Dele Adetoye identified vote buying as a breeder of distrust of the electorates on the leaders which is also included in the questionnaire as an impact of Vote Buying but further identified institutional fragility and unaccountability of leaders to the electorates as other impact of vote buying not mentioned in the questionnaire.

Hypothesis 3: There are no factors encouraging vote buying in 2018 Governorship election in ekiti states.

Table 4.28

One-Sample Test

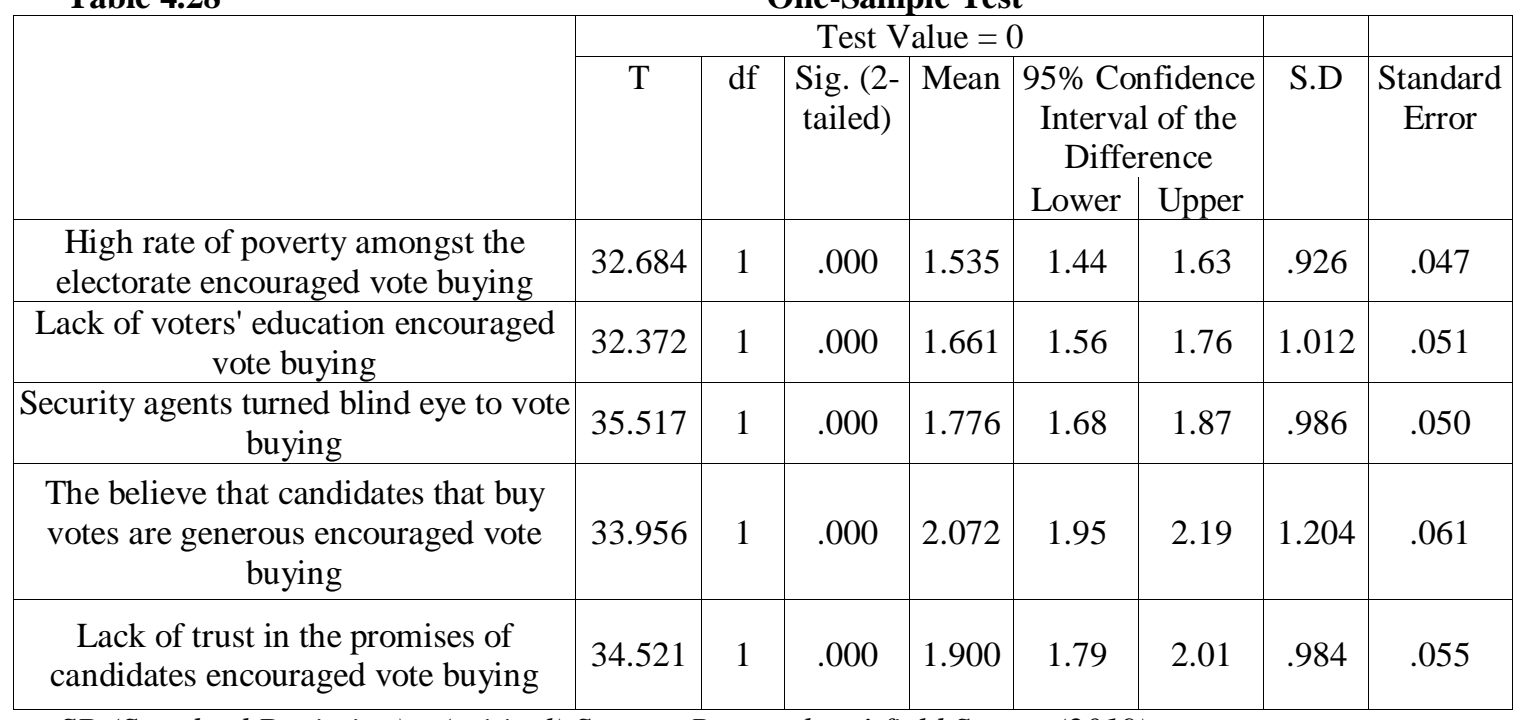

SD (Standard Deviation), t (critical) Source: Researchers' field Survey (2019)

The result above reveals that $t$ value for all the items are 32.684, 32.372, 35.517, 33.956 and 34.521 which are all positive, the degree of freedom for all the items are 1 , the $\mathrm{P}$ value for all the items are 0.00 which is less than $(<) 0.05$ and is statistically significant. Mean difference for all the items are 1.535, 1.661, 1.776, 2.072 and 1.900 the standard deviation is .926, 1.012, .986, 1.204 and .984 meaning that there is a concentration of view in agreement to questions asked on poverty, security agents turning a blind eye to vote buying and the lack of trust in the promises of candidates as factors encouraging vote buying while a wider range of views about lack of voters education and the believe that individuals who buy votes are generous candidates the standard error is $0.47, .051, .050, .061$ and .055 . This indicates that $P$ value of 0.00 which is statistically significant and the $t$ is positive. This implies that there were factors that encouraged vote buying in 2018 Governorship election in ekiti states. Notable among them identified in the research includes High rate of poverty among electorates and low voter education showcased in table 4.1.16 and 4.1.17 respectively therefore, the hypothesis is rejected. This conclusion is in alignment with the claims of all individuals interviewed for the research concerning the factors that encouraged vote buying in the 2018 governorship election in Ekiti State. The entire interviewed respondent ticked agreed that poverty and lack of voter's education are major factors encouraging vote buying which is in alignment with the questions on the questionnaire. However, Prof Dele Adetoye and The Public Relations Secretary of the 
(PPA) Ekiti Chapter agree that Security agents and view that voter buyers are generous candidates encourage vote buying in the 2018 governorship election in Ekiti state which is also captured in the questionnaires. Prof. Dele Adetoye identified other factors encouraging vote buying which include the NYSC corp. members, the INEC officials and the impatience of the Ekiti electorate to wait on the dividend of democracy are also factors encouraging vote buying

Hypothesis 4: Vote buying cannot be minimized in future election in Ekiti state.

Table 4.29

One-Sample Test

\begin{tabular}{|c|c|c|c|c|c|c|c|}
\hline & \multicolumn{5}{|c|}{ Test Value $=0$} & \multirow{3}{*}{ S.D } & \multirow{3}{*}{$\begin{array}{l}\text { Standard } \\
\text { Error }\end{array}$} \\
\hline & & \multirow[t]{2}{*}{ df $\left|\begin{array}{c}\text { Sig. }(2- \\
\text { tailed) }\end{array}\right|$} & \multirow[t]{2}{*}{$\begin{array}{c}\text { Mean } \\
\text { Difference }\end{array}$} & \multicolumn{2}{|c|}{$\begin{array}{l}\text { 95\% Confidence } \\
\text { Interval of the } \\
\text { Difference }\end{array}$} & & \\
\hline & & & & Lower & Upper & & \\
\hline $\begin{array}{l}\text { Vote buying should be added to the } \\
\text { criminal code and long term sentence } \\
\text { given to offenders }\end{array}$ & 34.4451 & .000 & 1.820 & 1.72 & 1.92 & 1.042 & .053 \\
\hline $\begin{array}{l}\text { Voter education should be conducted } \\
\text { before future elections }\end{array}$ & 31.8341 & .000 & 1.535 & 1.44 & 1.63 & .951 & .048 \\
\hline \begin{tabular}{|c|} 
Ekiti State Government should embark \\
on grass root poverty alleviation scheme \\
to prevent candidates from taking \\
advantage of the poor electorates \\
\end{tabular} & 35.8311 & .000 & 1.802 & 1.70 & 1.90 & .992 & .050 \\
\hline $\begin{array}{l}\text { EFCC and ICPC should investigate party } \\
\text { finances to curb vote buying }\end{array}$ & $\mid 36.2751$ & .000 & 1.779 & 1.68 & 1.88 & .967 & .049 \\
\hline $\begin{array}{l}\text { Candidates should be disqualified if } \\
\text { found guilty of vote buying }\end{array}$ & 31.9541 & .000 & 1.640 & 1.54 & 1.74 & 1.012 & .051 \\
\hline
\end{tabular}

SD (Standard Deviation), t (critical) Source: Researchers’ field Survey (2019)

The result above reveals that $t$ value for all the items are 34.445, 31.834, 35.831, 36.275 and 31.954 which are positive, the degree of freedom for all the items are 1 , the $\mathrm{P}$ value for all the items are 0.00 which is less than $(<) 0.05$ and is statistically significant. Mean difference for all the items are 1.820, 1.535, 1.802, 1.779 and 1.640. The standard deviations for all the items are 1.042, .951, .992, .967 and 1.012 meaning that the views of the respondent as it relates to voters education, provision of poverty alleviation programs and for the EFCC to investigate the accounts of political parties as mechanisms to minimize vote buying are concentrated while there is wider range of views about adding vote buying as a crime for capital punishment if found guilty and candidate been disqualified if found guilty as a mechanism to minimize vote buying. The standard error is 0.53 . This indicates that $P$ value of 0.00 which is statistically significant and the $t$ is positive. This means that vote buying can be minimized in future elections in Ekiti state, with collaborative efforts of the electoral umpire and security agencies, to ensure that party agents and public office holders whom are culpable of such acts are prosecuted. Therefore the hypothesis is rejected. This is also in alignment with the suggestions of individuals who were interviewed that until the factors that encourage vote buying are tackled and punishment of this behavior dealt with the behavior of vote buying will keep on thriving. 


\section{Discussion of Finding}

The analyses of the data in this study reveal that vote buying affects democratic election in general and 2018 Governorship election in ekiti state in particular. The result presented in table 4.26 shows that a large concentration of respondent acknowledged that the activities of vote buying within the 2018 Governorship election in Ekiti state was visibility manifested. This finding also aided in giving spotlight on some of the factors that contributed to the outcome of the election and the potency of these methods of vote buying see and buy (vote buying at the polling centre) and vote buying during campaign rallies which is in line with the views of the interviewed persons and the argument of other scholars who carried out similar research (Vicente, and Wantchekon, L, 2009; Nwankwo, 2018; Onuoha, and Ojo, 2018). The result presented in table 4.27 to ascertain if the impact of vote buying on the 2018 gubernatorial election was analysed using the one sample Ttest. Shows that there is a large concentration of respondent acknowledging the fact that vote buying had impact on the 2018 Governorship election in Ekiti state. It also aids to identify the pronounced impact of vote buying which includes corruption and lack of trust in the government, the structure and the institution presented in table 4.1.11 and 4.1.14 respectively. This results is however, in alignment with the contribution of different key informant interview and the works of others scholars such as (Bratton, 2008; GonzalezOcantos et, al. 2012).

The result presented in table 4.28 to determine the factors encouraging vote buying in 2018 Governorship Election in Ekiti state was analysed using the one sample t-test. This shows that there is a large concentration of respondent acknowledging the fact that poverty, security agents turning a blind eye to vote buying and the lack of trust in the promises of candidates are factors encouraging vote buying while a wider range of views about lack of voters education and the believe that individuals who buy votes are generous candidates implies that there were several factors that encouraged vote buying in 2018 Governorship election in ekiti states. Notable among them identified in the research includes High rate of poverty among electorates and low voter education showcased in table 4.1.16 and 4.1.17 respectively. This results is however, in alignment with the contribution of different key informant interview and the works of others scholars such as (Fredrick, and Andreas, 2005; Jensen, and Justesen, 2014). The result presented in table 4.29 to investigate ways in which of vote buying can be minimized future Ekiti state elections was analysed using the one sample T-test. This shows that there is a large concentration of the respondent as it relates to voters education, provision of poverty alleviation programs and for the EFCC to investigate the accounts of political parties as mechanisms to minimize vote buying are concentrated while there is wider range of views about adding vote buying as a crime for capital punishment if found guilty and candidate been disqualified if found guilty as a mechanism to minimize vote buying. This means that vote buying can be minimized in future elections in Ekiti state, with collaborative efforts of the electoral umpire and security agencies, to ensure that party agents and public office holders whom are culpable of such acts are prosecuted. The outcome of the finding aids identifying what mechanism in put in place will minimize the growth of vote buying in future Ekiti elections this result is in tandem with the works of different scholars such as (Iyayi, 2005; Adetoye, and Omilusi, 2016; Adamu, A. Ocheni, and Ibrahim, 2016). 


\section{Summary, Recommendation And Conclusion}

\section{Summary}

The main aim of this research was to place the spotlight on the manifestation of vote buying, impact of vote buying, catalyst of vote buying and how to minimize or curb the growth of vote buying in future Nigerian elections. The motivation for this research came out of the review of other literature such as (Bratton, 2008; Carreras, and Irepoglu, 2013; Jensen, and Justesen, 2014) which revealed that little literature had been done concerning depicting the impact of vote buying in new democracies and societies like that of Ekiti state which was further made necessary by the unconfirmed allegation of INEC about the magnitude of vote buying in Ekiti state (Oyenigbehin, 2018). The research shows that there was ample impact of vote buying on democratic elections in the 2018 Governorship election in Ekiti States. The impacts of vote buying on elections in Ekiti State have both immediate and delayed impacts. The immediate impact affect the fundamental principle of representative democracy were the true wishes and desires of the people are no longer represented through elections but are controlled through inducement of money by the different political candidates, resulting to unaccountable leaders. Vote buying further results in lack of trust in the system and institutional fragility which is ticking bomb for anarchy and increase in crime

\section{Recommendations}

In reality the braze acts of vote-buying cannot be eradicated totally however, specific mechanism should be put in place to reduce the growth and negative effort of vote buying on the electoral process and democracy such as partnership between The Independent National Electoral Commission and the anti-corruption agencies such as the Economic and Financial Crimes Commission while conducting elections and afterward culprits found in vote buying should be handed over to these agencies for investigation and prosecution.

Existing electoral legislation needs to be amended and stringent punishment attached in order to mitigate the advancement of vote buying such as the addition of Capital Punishment for offenders.

Increase in Voter Education were the government does not leave it to Non-governmental agencies but be involved by including voters education to school curriculum as part of social studies and civic education, organizing talk shows and workshops about the woes of vote buying.

Improved Poverty Alleviation Schemes need to be implemented so as to counter acts its effort as a catalyst for vote buying.

Disqualification of Guilty Candidates and prosecution of culprits of vote buying should be taken seriously as criminalized by sections 124 and 130 of the Electoral Act 2010, as amended.

Scrutinizing of Party Finances through mandatory compliance from the parties according to the Electoral Act 2010 concerning submission of account statement, expenditure of the party, an audit of the books of the party before and after an election must be enforced in order to trace suspicious transactions and action of vote buying 


\section{Contribution to Knowledge}

The research contributes to the knowledge by increasing the wealth of literature on the subject of vote buying and democratic elections in Nigeria. This research contribution is significance because although a lot of literature has be written on vote buying as well as democratic election but very little has be done in showing how deep the behaviour of vote buying has dug into the fabric of democratic elections which is the hallmark of representative democracy especially to a growing democracy like Nigeria. The quantitative approach applied to the research aid to give quantifiable result of the nature of vote buying in Nigeria's election and a departure from the norm of accepting declarations from either pro or anti party members about vote buying in Nigerian election

This research also has theoretical, governmental and statistical contribution. Theoretical contribution, the research of vote buying and democratic election using Ekiti state as a case study expands on the already existing literature on vote buying and Democratic elections in Nigeria. As the present literature review shows that there are limited studies done in Nigeria such as Bratton (2008) who examines Vote buying and Violence in Nigerian election campaigns, Ovwasa (2012) who examines Money Politics and Vote Buying in Nigeria: As the Bane of Good Governance as well as the application of the theory of clientalism in relationship to understanding vote buying

Governmental contribution as the present mode of election engineering carried out by political candidate creates an impediment to democratic elections and her growing democracy. Hence, exploring the nature, extent and effectiveness of irregular campaign methods such as vote buying is geminin to future elections. This research also throws light to who are the victims of vote buying in Nigeria with Ekiti state as a case study and what are the possible voter behaviors in responses to irregular campaign method like vote buying. Bratton (2008) explains that voter's behavior at the individual level when introduced to irregular campaign methods like vote buying can be classified into three possible course of action namely to refuse, to defect, or to comply. These three courses of actions are very important in understanding the outcome of the election in Ekiti state. The finding of the research offer valuable insight into how the government can tackle the issue of vote buying in future elections

Statistically, the research employs the T-test which is a great addition to previous studies both in Nigeria and other countries. Other studies have done relationship between electoral turnout and candidate popularity as a function of vote buying but the t-test exposes the degree at which the menace of vote buying has largely dogged into the fabrics of democratic elections in Nigeria

\section{Limitation of the research}

The challenges encountered in this research were mainly related to primary data gathering. The human factor which cannot be totally removed in form of biases, lack of total transparency and lack of willingness to release certain information that are vital to the research under the pretext classified information. Other issues include the scope of the research which is Governorship election in ekiti state as a case and making assertions about Nigeria as a whole.

The research also suggest that more research should be carried to determine when vote buying fails and what were established by the government or the factors that contributed to the failure especially in the 2018 Anambra State Gubernatorial Election 


\section{Conclusion}

Vote buying has great set back on the electoral process of Nigeria and is a threat to her democracy as it promotes corruption, poverty, decline in political participation and increase in crime. Some catalysts of vote buying include poverty, ignorance, ineffective sanction on culprits and distrust of the government. Vote buying isn't a new phenomenon but a practice that has been old as the Nigeria. Nevertheless it still remains an electoral offence therefore; culprits should be brought to book. Vote buying isn't done in isolation, however, for the system to work it is necessary that the perpetuators within the system be flushed out. This is because if a candidate decides to begin his/her political journey with corruption by paying for support, rather than competing for votes fair and square. It can be concluded that such candidates has no regard for democratic procedures and is open to using illegal means in his/her administration.

\section{References}

1. Abia, B., W. (2006). Understanding Nigerian Government and Politics. Maryland: Gofaflesh Publication Limited

2. Adamu, A., Ocheni, D. and Ibrahim, C. (2016). Money politics and analysis of voting behavior in Nigeria: challenges and prospects for free and fair elections International Journal of Public Administration and Management Research. Vol. 3, No. 3, pp 89-99

3. Adeseun, A. (2017). INEC Releases Timetables for Ekiti and Osun 2018 Governorship

Elections. Retrieved from Nigerian Monitor online http://www.nigerianmonitor.com/ inecs timetables-for-ekiti-osun-2018-governorship-elections/ accessed on 22/02/2019

4. Adetoye, D. and Omilusi, M. (2016). Pains of Development and Electoral Politics in Nigeria's Democracy: Ekiti State in Perspective. European Journal of Research in Social Sciences. Vol.4 No.1, pp. 27-33

5. Adetoye, M.A (2010) the Politics and Contradictions of Ekiti State Creation. A Doctoral Thesis submitted to the Department of Political Science, Faculty of the Social Sciences, University of Ibadan

6. $\quad$ Akamere, F., A. (2001). Government Made Easy. Lagos: Olu Abbey Modern Press.

7. Akinkuotu, E. (2018). INEC decries 'vote-buying' in Ekiti governorship election The Punch retrieved from https://punchng.com/inec-decries-vote-buying-in-ekiti-governorship election/ accessed on 23/12/2018

8. Animashaun, M. (2015). Nigeria 2015 Presidential Election: The Votes, the Fears and the Regime Change. Journal of African Elections. Vol. 14, No. 2, pp. 186-211. https://hdl.handle.net/10520/EJC183719 9. AuwalAbubkar, C., MohdMahadee, I. and Ku Hasnita, S. (2017). An Assessment of the Role of Money in Nigerian General Election. Journal of Humanities and Social Science. Vol. 3, pp.61-65

10. Ayeni-Aleke, O., A. (2008). Foundation of Political Science. Ibadan: Ababa Press Limited

11. Baidoo, F. L., Dankwa, S. and Eshun, I. (2018). Culture Of Vote Buying and Its Implications: Range of Incentives and Conditions Politicians offer to Electorates International Journal of Developing and Emerging Economies Vol.6, No.2, pp.1-20

12. Bamgbose, J., A. (2012). Electoral Violence and Nigeria's 2011 General Elections. International Review of Social Sciences and Humanities. Vol. 4, No. 1. pp. 205-219

13. Beyer, A., Knutsen, C. and Rasch, B. (2014). Election Campaigns, Issue Focus and Voting Intentions: Survey Experiments of Norwegian Voters. Scandinavian Political Studies.Vol. 37, No. 4, pp. 406-427 https://doi.org/10.1111/1467-9477.12029

14. Birch, S. (2010). Perceptions of electoral fairness and voter turnout. Comparative Political Studies. Vol. 43 No. 12, pp. 1601-1622 https://doi.org/10.1177/0010414010374021

15. Bonett, D. and Wright, T. (2014). Cronbach's alpha reliability: Interval estimation, hypothesis testing, and sample size planning. Journal of Organizational Behavior. Vol 7. No. 4, pp.50-63 https://doi.org/10.1002/job.1960 
16. Bratton, M. (2008). Vote buying and violence in Nigerian election campaigns. Electoral Studies.

Vol 27, pp. 621-632 https://doi.org/10.1016/j.electstud.2008.04.013

17. Caciagli, M. and Belloni, F. (1981). The "New" Clientelism in Southern Italy: The Christian Democratic Party in Catania’, in Shmuel Eisenstadt and René Lemarchand (eds.), Political Clientelism, Patronage and Development. London: Sage, pp.35-56

18. Carreras, M and Irepoglu, Y (2013) Trust in elections, vote buying, and turnout in Latin America Electoral Studies. Vol. 32, pp. 609-619. https://doi.org/10.1016/j.electstud.2013.07.012

19. Center for Democracy and Development (2018) Ekiti State 2018 Governorship Election.

20. Channels Television (2018). INEC announces Ekiti Governorship Election Results Full Listretrieved from Channels TV. Online https://www.channelstv.com/2018/07/15/inecannounces-ekitigovernorship-election-results-full-list/ 22/02/2019

21. Check Market (2019). Sample size calculator retrieved from https://www.checkmarket.com/samplesize/-calculator accessed on the 23/02/2019

22. City Population. (2017). Ekiti State In Nigeria retrieved from https://www.citypopulation.de/php/nigeria-admin.php?adm1id=NGA013 accessed on the 21/02/2019

23. Daily Trust (2019). Comparison of 2015 vs 2019 Presidential election Results. Retrieved from Daily Trust online https:/www.dailytrust.com.ng/comparison-of-2015-vs-2019presidential-election-result.html 24/01/2019

24. Daniel, S. and Agbakwuru, J. (2014). 2015 Presidential Election: Campaigns start Nov 16. Retrieved from Vanguard online https://www.vanguardngr.com/2014/01/2015 presidential-election-campaignsstart-nov-16/ 25/01/2019

25. David, N., Manu, Y. and Musa, A. (2014). Elections, Electoral process and the challenges of democratization in Nigeria's fourth republic Research on Humanities and Social Sciences Vol.4, No.17, pp. 93-102

26. Dudley, B., J. (1982). An Introduction to Nigerian Government and Politics. London: TheMacmillan Press

27. Eisenstadt, S. and Lemarchand, R. (1981). Political Clientelism, Patronage and Development. London: Sage

28. Elaigwu, I. (2005). The Politics of Federalism in Nigeria. Jos: Aha Publishing House Limited.

29. Electoral Act (2010) retrieved from https://nai.uu.se/library/resources/thematicresources/ elections -in-nigeria-2011/2010_Electoral_Act.pdf24/01/2019

30. Elekwa, N. (2008). The Electoral Process in Nigeria: How to Make INEC Succeed TheNigerian Electoral Journal. Vol. 2 No.1, pp. 30-42.

31. European Union (2003). Nigeria 2003 Election Final Report. Frankfurt: European Union Election Observation Mission

32. Fafchamps, M. and Vicente, P.C. (2013). Political violence and social networks: Experimental evidence from a Nigerian election Journal of Development Economics Vol. 101, pp. 27-48 https://doi.org/10.1016/j.jdeveco.2012.09.003

33. Fasuan, O. (2002). Creation of Ekiti State: The Epic Struggle of a People Ado-Ekiti: Industrial and Merchandise Nigeria Limited

34. Franklin, N. (2004). Voter Turnout and the Dynamics of Electoral Competition in Established Democracies since 1945. Cambridge: Cambridge University Press

35. $\quad$ Fredrick C., S. and Andreas, S. (2005). What is Vote Buying, The Limit of Market Model apaper presentation at the conference of 'Poverty' Democracy and Clientism: The Political Economy of Vote Buying. Department of Political Science, Stanford University.

36. Gberie, L. (2011). The 2011 Elections in Nigeria: A New Dawn. Pretoria: Institute for Security Studies.

37. Gellner, Ernest and John Waterbury (eds.) (1977). Patrons and Clients in Mediterranean Societies. London: Duckworth, pp.1-6.

38. Gonzalez-Ocantos, E., Jonge, E., Meléndez, C., Osorio, J. and Nickerson, D. (2012). Vote Buying and Social Desirability Bias: Experimental Evidence from Nicaragua. American Journal of Political Science. Vol. 56, No. 1, pp. 202-217 https://doi.org/10.1111/j.1540-5907.2011.00540.x

39. Grbeša, M. (2004). To What Extent and in What Ways do Election Campaigns Matter?Politička Misao. Vol. 42, No. 5, pp. 87-95 
40. Heale, R. and Twycross, A. (2015). Validity and Reliability in Quantitative Studies. Evidence Based Nursing Vol. 18 No. 3, pp. 66-69

41. Human Rights Watch. (2004). Nigeria's 2003 Elections: The Unacknowledged Violence. New York 42. Ibrahim, J. (2007). Nigeria's 2007 Elections: The Fitful Path to Democratic Citizenship. Washington, DC: United States Institute of Peace

43. INEC 2007. The Official Report on the 2007 General Elections. Abuja: Independent National Electoral Commission

44. Inokoba, P.K. and Kumokor (2011) Electoral crisis and Democratic consolidation in Nigeria Journal of Social Science Vol. 27 No. 2, pp. 139-148

45. Iyayi, F. (2005). Elections and Electoral Practices in Nigeria: Dynamics and Implications, The

Constitution: Journal of Constitutional Development.Vol.5, No 2, pp. 120-140 https:/hdl.handle.net/10520/AJA15955753_129

46. Jadesola, B. (2012). Political Ties and Challenges of Ekiti since Colonial Era Being A Paper Submitted For Assessment Towards Publication In The Ado-Ekiti Project

47. Jadesola, B. (2017). Agitations for State Creation in Nigeria: A Study of Ekiti State. Ekiti State University Journal of History and International Studies Vol. 5 No. 1, pp. 52-63

48. Jensen, P., S. and Justesen, M., K. (2014). Poverty and vote buying: Survey-based evidence from Africa. Electoral Studies. Vol. 33, pp. 220-232 https://doi.org/10.1016/j.electstud.2013.07.020

49. Katz, R. (1986). Preference Voting in Italy: Votes of Opinion, Belonging or Exchange. Comparative Political Studies. Vol. 18 pp. 229-49

50. Kimberlin, C and Winterstein, L (2008). Validity and reliability of measurement instruments used in research. Am J Health-System Pharmacy. Vol. 65 No. 23, pp. 2276-2284. https://doi.org/10.2146/ajhp070364

51. Loeb, S., Dynarski, S., McFarland, D., Morris, P., Reardon, S., and Reber, S. (2017). Descriptive analysis in education: A guide for researchers. Washington, DC: U.S. Department of Education, Institute of Education Sciences.

52. Malhotra, N. (2010). Marketing Research: an applied orientation London: Pearson Education, Inc

53. Manheim, H. (1977). Sociological Research: Philosophy and Methods. Illinois: The DorseyPress

54. Momoh, A. (August 19, 2005). Democracy or Good Governance Making Sense of Disempowerment in Nigeria. The Guardian Newspaper

55. Moshood, B., A. (2009). Election Rigging and Governance in Nigeria: An Appraisal. LASU Journal of Humanities. Vol.6 pp. 98-108

56. Neeman, Z. and Orosel, G.O (2006). On the efficiency of vote buying when voters have common interests International Review of Law and Economics Vol. 26, pp. 536-556 https://doi.org/10.1016/j.irle.2007.01.006

57. Nemoto, T., \& Beglar, D. (2014). Developing Likert-scale questionnaires. In N. Sonda \& A. Krause (Eds.), JALT2013 Conference Proceedings. Tokyo: JALT

58. $\quad$ Nichter, S. (2014). Conceptualizing vote buying Electoral Studies Vol. 35, pp. 315-327

59. Nnamani, D., O. (2014). Electoral Process and Challenges of Good Governance in the Nigerian State (1999-2011) Journal of Good Governance and Sustainable Development in Africa (JGGSDA), Vol. 2, No 3, pp. 78-99

60. Noah, Y. (2006). The Democratisation Process and Industrial Relations Practice In Hassan, Saliu., Ebele, Amali., Joseph, Fayeye and Emmanuele Oriola (eds). Democracy and Development in Nigeria Volume 3 Social Issues and Extended Relations. Lagos: Concepts Publications Limited

61. Nseyen, N. (2018). INEC declares Fayemi winner of Ekiti governorship election retrieved from The Daily Post online https://dailypost.ng/2018/07/15/breaking-inec-declares-fayemi winner-ekitigovernorship-election-2/ accessed on the 02/03/2019

62. Nwankwo, F., C. (2018). Vote Buying in the 2018 Governorship Election in Ekiti State, Nigeria. Open Political Science. Vol. 1, pp. 93-97 https://doi.org/10.1515/openps-2018-0005

63. Nwaubani, A., T. (2014). Letter from Africa: Nigeria’s Internet Warriors, in: BBC News, 23 September

64. Nwokeke, O. and Jayum, J. (2011). The Electoral Process and Democratic Consolidation in Nigeria. Journal of Politics and Law Vol. 4, No. 2, pp. 128-138

65. Odusote, A. (2014). Nigerian Democracy and Electoral Process since Amalgamation: Lessons from a Turbulent Past. Journal of Humanities and Social Science. Vol. 19, No. 10, pp.25-37 
66. Ogbeidi, M. (2010). A Culture of Failed Elections: Revisiting Democratic Elections in Nigeria, 1959-2003. HAOL, Vol. 21, pp. 43-56

67. Oguntola, T. (2018). Vote Buying, Electoral Fraud and The 2019 Elections retrieved from Leadership online https://leadership.ng/2018/10/04/vote buying-electoral-fraud and the-2019 elections/ 04/02/2019

68. Ojo, J. (2018). Electoral violence, vote-buying and Nigeria's future elections retrieved from Punch online https://punchng.com/electoral-violence-vote-buying-and-nigerias-future elections/ accessed on 03/02/2019

69. Olowojolu, O. and Ake, M. (2015). An Overview of 2015 General Elections in Nigeria. Arabian Journal of Business and Management Review. Vol. 5, No.5, pp. 13-20

70. Onuoha, F. and Ojo, J. (2018). Practice and Perils of Vote Buying in Nigeria's Recent Election Pretoria: African Center for the Constructive Resolution of Dispute

71. $\quad$ Orji, N. (2015). The 2015 Nigerian General Elections. Africa Spectrum. Vol. 50, No. 2, pp. $73-85$.

72. $\quad$ Orji, N. and Uzodi, N. (2012). The 2011 Post Election Violence in Nigeria. Abuja: Policy and Legal Advocacy Centre (PLAC)

73. Oromareghake, P., M. (2013). Electoral Institutions/Processes and Democratic Transition in Nigeria under the Fourth Republic. International Review of Social Sciences and Humanities. Vol. 6, No. 1, pp. 19-34 74. Osabiya, J. (2014). Nigeria and Democratic Election. Journal of Good Governance and Sustainable Development in African Studies (JGGSDA). Vol. 2, No. 3, pp. 53-64

75. Osaghae, E. (1999). Democratization in sub-Saharan Africa: Faltering prospects, new hopes. Journal of Contemporary African Studies. Vol. 17, No. 1, pp. 4-25. https://doi.org/10.1080/02589009908729636

76. Ovwasa O., L. (2013) Money Politics and Vote Buying in Nigeria: The Bane of Good Governance Afro Asian Journal of Social Sciences Vol. 4, No. 4.3 pp. 119 DOI: 10.5901/mjss.2014.v5n7p99

77. Owete, F. (2014). Nigeria2015: Analysis: APC Presidential Primary: How the candidates stand Retrieved from Premium times online https://www.premiumtimesng.com/news/172848 apc-presidentialprimary-how-the-candidates-stand.html 21/01/2019

78. Owete, F. (2014). Nigeria2015: PDP Presidential Primaries Live Updates. Retrieved fromPremium times online https://www.premiumtimesng.com/investigationspecial reports/172890-nigeria2015-pdppresidential-primaries-live-updates.html 23/01/2019

79. Oyenigbehin, J. (2018). INEC calls for criminalization of vote buying retrieved from TheVanguard online https://www.vanguardngr.com/2018/07/inec-calls-for-criminalisation of-vote-buying/ accessed on $12 / 02 / 2019$

80. Palys, T. (2008). Purposive sampling. In Given, L. (Ed.) The Sage Encyclopedia of Qualitative Research Methods. Vol.2, pp. 697-698.

81. Parisi, A. and Pasquino, G. (1979). Changes in Italian Electoral Behaviour: The Relationships Between Parties and Voters, in Peter Lange and Sidney Tarrow (eds.), Italy in Transition. London: Frank Cass, pp.6-30.

82. $\quad$ Piattoni, S. (ed.) (2001). Clientelism, Interests, and Democratic Representation. Cambridge: Cambridge University Press

83. Sahara reporters, (2018). Live Ekiti State Governorship Election. Retrieved from http://saharareporters.com/2018/07/14/live-ekiti-state-governorship-election ～06/03/2019

84. Sakariyau, R., Aliu, F., L. and Adamu, M. (2015). The Phenomenon of Money Politics and Nigeria's Democratization: An Exploration of The Fourth Republic Journal of Social Economics Research. Vol. 2, No. 1, pp. 1-9 DOI: 10.18488/journal.35/2015.2.1/35.1.1.9

85. Silva, C. (2017). Research Design - The New Perspective of Research Methodology. British Journal of Education, Society \& Behavioural Science. Vol. 19, No. 2, pp.1-12. DOI: 10.9734/BJESBS/2017/30274

86. Taherdoost, H. (2017). Determining Sample Size; How to Calculate Survey Sample Size International Journal of Economics and Management Systems Vol. 2 pp. 237-239

87. Tarrow, S. (1967). Peasant Communism in Southern Italy. New Haven: Yale University Press 88. The Cable (2014). Akinyemi writes Jonathan and Buhari, warns on impending post-election। bloodshed Retrieved from The Cable online https://www.thecable.ng/akinyemi-writes jonathan-buhariwarns-impending-post-election-bloodshed 19/02/2019

89. The Carter Center (1999). Observing the 1998-99 Nigeria Elections National Democratic Institute for International Affairs 
90. This day (2018). 2018 Ekiti State Gubernatorial Election Final Result retrieved from This Dayonline https://www.thisdaylive.com/index.php/2018/07/15/2018-ekiti-state-gubernatorial election-finalresult/ accessed on the 07/03/2019

91. Thomas-Odia, I. (2018). Vote buying has been part of Nigeria's polling process retrieved fromThe Guardian online https://guardian.ng/politics/vote-buying-has-been-part-of-nigerias ～polling-process/ accessed on 14/02/2019

92. Transition Monitoring Group. (2003). Do the Votes Count: Final Report of the 2003 General Elections in Nigeria. Abuja.

93. Uduak-Obong, E. and Forsberg, O. (2018). An Analysis of the 2015 Nigerian PresidentialElection. Pursue Journal. Vol. 1, pp. 5-20

94. Ugochukwu, B. (2009). Democracy by Court Order: An Analytical Evaluation of the 2007 Election Petition Tribunals in Nigeria. Lagos: Legal Defence Centre.

95. Ugoni, A. and Walker, B. (1995). The T-Test: An introduction. Comsig Review. Vol.4. No. 2, pp. $37-41$

96. Vanguard (2015). Presidential Election results as announced by INEC. Retrieved from Vanguard online https://www.vanguardngr.com/2015/03/enugu-results-by-inec/ accessed on the 05/02/20

97. Vanguard, (2011). Presidential Elections 1999-2011 in-figures. Retrieved from Vanguard online https://www.vanguardngr.com/2011/04/presidential-elections-1999-2011-in-figures/ accessed on $14 / 02 / 2019$

98. Vicente, P. and Wantchekon, L. (2009). Clientelism and Vote Buying: Lessons from field experiments in African elections. Oxford Review of Economic Policy. Vol. 25, No. 2, $\quad$ pp. 292-305 https://doi.org/10.1093/oxrep/grp018

99. Weingrod, A. (1968). Patrons, Patronage and Political Parties. Comparative Studies in Society and History Vol.10, pp. 377-400.

100. YIAGA Africa (2018). Pre-Election Observation Ekiti 2018 Gubernatorial Election retrieved from http://yiaga.org/wp-content/uploads/2018/06/PREO-1.pdf accessed on the 07/03

101. Zikmund, W. (1988). Business Research Methods. Chicago: The Dryden Press Creative Commons Attribution - Non Commercial - No Derivatives 4.0 International License. 